\title{
Finding Oxford's medieval Jewry using organic residue analysis, faunal records and historical documents
}

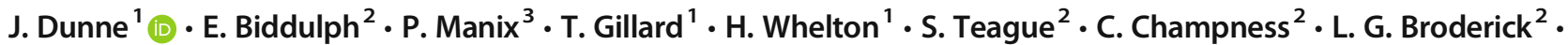

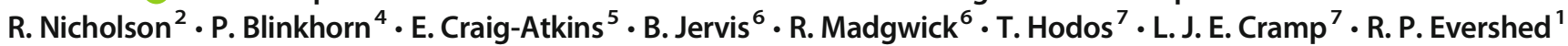

Received: 24 September 2020 / Accepted: 14 January 2021 / Published online: 20 February 2021

(C) The Author(s) 2021

\begin{abstract}
Food is often one of the most distinctive expressions of social, religious, cultural or ethnic groups. However, the archaeological identification of specific religious dietary practices, including the Jewish tradition of keeping kosher, associated with ritual food practices and taboos, is very rare. This is arguably one of the oldest known diets across the world and, for an observant Jew, maintaining dietary laws (known as Kashruth) is a fundamental part of everyday life. Recent excavations in the early medieval Oxford Jewish quarter yielded a remarkable assemblage of animal bones, marked by a complete absence of pig specimens and a dominance of kosher (permitted) birds, domestic fowl and goose. To our knowledge, this is the first identification of a Jewish dietary signature in British zooarchaeology, which contrasted markedly with the previous Saxon phase where pig bones were present in quantity and bird bones were barely seen. Lipid residue analysis of pottery from St Aldates showed that vessels from the possible Jewish houses were solely used to process ruminant carcass products, with an avoidance of pig product processing, correlating well with the faunal data. In contrast, lipid analysis of pottery from comparative assemblages from the previous Saxon phase at the site and a contemporaneous site in the city, The Queen's College, shows that the majority of these vessels appear to have been used to process mixtures of both ruminant and non-ruminant (pig) products. Here, the combination of organic residue analysis, site excavation and animal and fish bone evidence was consistent with the presence of Jewish houses in eleventh- and twelfth-century St Aldates, Oxford, hitherto only suspected through documentary information. This is the first identification of specific religious dietary practices using lipid residue analysis, verifying that, at least 800 years ago, medieval Jewish Oxford communities practised dietary laws known as Kashruth.
\end{abstract}

Keywords Organic residues $\cdot$ Isotopes $\cdot$ Medieval $\cdot$ Jewish $\cdot$ Oxford $\cdot$ Faunal assemblage

J. Dunne

julie.dunne@bristol.ac.uk

1 Organic Geochemistry Unit, School of Chemistry, University of Bristol, Cantock's Close, Bristol BS8 1TS, UK

2 Oxford Archaeology, Janus House, Osney Mead, Oxford OX2 0ES, UK

3 Chipping Norton, UK

4 Northampton, UK

5 Department of Archaeology, University of Sheffield, Minalloy House, 10-16 Regent Street, Sheffield S1 3NJ, UK

6 School of History, Archaeology and Religion, Cardiff University, Cardiff CF10 3EU, UK

7 Department of Anthropology and Archaeology, University of Bristol, Bristol BS8 1UU, UK

\section{Introduction}

The consumption of food is a biological necessity and, as such, central to human life. Everyone must eat, but the meanings of what, where, how, when and with whom they eat are culturally prescribed. Food itself, the preparation of food through cooking practices, and eating, all serve to create and maintain social relationships. Food has long been linked with ethnicity, religion, race, nationality, class and, sometimes, gender (Twiss 2012) and food and cuisine can be one of the most distinctive expressions of a social, religious, cultural or ethnic group. The food and foodways of ethnic groups symbolise tradition and community (Tuchman and Levine 1993) and, for these groups, as Hamilakis (2000) notes, 'sharing the same food habits, eating the same staple, results in social integration and cohesion'. At the same time, food can be imbued with codes of exclusion and inclusion (Goody 1982; 
Caplan 1997; Cesaro 2000) and may be a marker of difference, setting groups apart (Mintz and Du Bois 2002).

In Jewish culture, food and eating are strongly related to identity. As Greenspoon et al. (2005) notes, for Jews, 'food has been used as a means of exclusion and persecution although, conversely, it has also been an instrument of community, reparation and renewal of identity'. Jewish food and cuisine consist of active social practices described by Rosenblum (2010) as 'bundled sets of social activities that allow one to signal overtly his or her perceived relationship to a given identity'. The strong relationship between Jewish food practices and identity, throughout history, can be ascribed to the exalted status bestowed upon food by the Hebrew Bible. For Jewish people, rules about food, particularly in terms of prohibitions against eating blood and requirements to bless food, serve as opportunities to serve and respect God. Central to the Jewish faith is the daily observance of the laws of Kashruth, extensive and complex rules that define what is and what is not fit for consumption (Kraut 1979).

\section{Jewish dietary practices}

Keeping kosher is arguably one of the oldest known diets across the world and, for an observant Jew, maintaining these dietary laws (known as Kashruth) is a fundamental part of everyday life. It is a key part of what identifies them as Jews, both among their own communities and to the outside world. The Kashruth (or kashrus, kashrut) or kosher laws are the 'totality of the laws and practices which are derived from the Jewish dietary commandments' (Freedman 1970). These determine which foods are 'fit or proper' for consumption by Jewish people who observe these laws (Regenstein and Regenstein 1979, 1988; Regenstein and Regenstein 1991; Regenstein et al. 2003) and deal predominantly with three main issues, permitted animals, prohibiting the ingestion of blood and the prohibition of mixing meat and milk. Anything that is not kosher is considered unfit for human consumption by Jews (Regenstein et al. 2003; Greenfield and Bouchnick 2011).

These laws are biblical in origin deriving from the Torah, the original five books of the Holy scriptures, and thought to be conceptualizations of divine will that were expressed to Moses at Mount Sinai (Grunfeld 1972). For example, the prohibition against mixing meat and milk is based on the threetimes repeated biblical quote 'Thou shalt not seethe the kid in the milk of its mother' first mentioned in the Torah in Exodus XXIII:19 and then in Exodus XXXIV:26 and Deuteronomy $\mathrm{XIV}: 21$. This prohibition is extremely serious and requires the complete separation of meat and dairy products and associated equipment (Grivetti 1980; Regenstein et al. 2003).

The Torah divides all beings into four groups, domesticated animals, birds, fish and insects and reptiles. Acceptable animals are defined as mammals that chew their cud and have a split hoof, which effectively means ruminant species, such as cattle, sheep and goat. Other species such as pig, horse and all amphibians and reptiles are considered ritually unfit. With regard to birds/fowl, the Torah only names species that are not kosher, including birds of prey, but states that three signs are given to kosher birds, a crop, an extra finger and a gizzard that can be peeled. In fact, the consumption of fowl is high in the Jewish diet and masorah (tradition) allows the consumption of chicken (Gallus gallus domesticus), geese (Anser sp.), duck (Anas sp.), swan (Cygnus cygnus), turkey (Meleagris gallopavo), doves and pigeon (Columba sp.) (Greenfield and Bouchnick 2011). Fish must possess scales and gills to be considered kosher, all others are not. This includes all crustacean and molluscan shellfish and fish such as sharks (Lamniformes sp.), catfish (Siluriformes sp.), dogfish (Squalidae sp.) and monkfish (Lophius piscatorius). Commonly consumed kosher fish include carp (Cyprinus carpio), salmon and trout (Salmoniformes sp.) and bass (Dicentrarchus labrax). Almost all insects are prohibited, save for a few types of grasshoppers (Caelifera), but today, honey and shellac (lac resin), used to coat sweets, are permitted (Regenstein et al. 2003).

One of the fundamental requirements of Jewish dietary practices includes the practice of shechita which refers to the traditional ritual slaughtering of animals. Slaughter is a ritual process performed by a trained, religious person (shochet), which must be followed very closely, beginning with the cutting of the jugular vein with a special knife called a chalef, and the subsequent draining of all blood from the body. The animal is then inspected for any physiological abnormalities and any with injuries or disease being deemed non-kosher. Next, the sciatic nerve must be removed, a process known as porging or deveining (Regenstein et al. 2003; Greenfield and Bouchnick 2011), as Jews are forbidden from eating the sinew that surrounds the sciatic nerve of the hind leg of domestic ruminants, gid hanasheh, also known as the 'sinew of Jacob'. This is very difficult and time-consuming and, in the USA and most other Western countries today, the hind legs are simply removed and sold as non-kosher. Significantly, this anatomical restriction is something that can, in theory, be identified in the archaeological record, through the absence of hind leg bones in an assemblage (Daróczi-Szabó 2004). Following the removal of the sinew (or discard of the hind leg), red meat and poultry must then be soaked, salted and then thoroughly drained, all within $72 \mathrm{~h}$ of slaughter, to further remove all prohibited blood (Regenstein et al. 2003).

One of the main features of modern kashrut is the maintenance of separate dishes for dairy and meat. In modern times, this includes all kitchen equipment such as pots, pans, utensils, a separation which sometimes extends to sinks, countertops and refrigerators (Kraemer 2005). It is not entirely clear when this prohibition came into place but the practice is certainly discussed by various medieval rabbinic authorities, for 
example, Rabbi Simha ben Samuel of Vitry (d. 1105) and Rabbi Jacob ben Asher (1275-1340) both state that pots used to cook meat should not be used to cook milk within $24 \mathrm{~h}$ (Kraemer 2005). In 1530, Antonius Margaritha from Regensburg, Bavaria, a Jewish convert to Christianity, writes that 'the Jews use two kinds of vessels, one for meat and the other for milk. Therefore, they have two kinds of pots, bowls, spoons, platters and knives'. M. Marcus, from London, in his 'The ceremonies of the Present Jews' from 1728/29 also notes that the Jews have 'two sets of dishes. Plates, knives, and forks for meat, and another for butter, milk and cheese' (Kraemer 2005).

\section{Medieval Jewish Oxford}

The city of Oxford emerged as an Anglo-Saxon burh, from the original eighth-century monastic settlement of St. Frideswide, at a ford near the confluence of the rivers Thames and Cherwell. By the tenth century, a system of mills had made much of the floodplain more stable and a walled Anglo-Saxon city grew on the gravel to the north. The dominant organizational element of the city was a four-ways cross, known as Carfax, running north/south, east/west and meeting in the centre of the roughly square burh. Later, the Normans established a royal castle dominating a position between the old Anglo-Saxon city walls and the river Thames. The Norman city walls were extended to incorporate this castle as well as a large eastern suburb along the London road, nearly doubling the size of Oxford (Fig. 1).

The twelfth and thirteenth centuries saw the development of Oxford's Jewish quarter around St Aldates (Fig. 2), following William the Conqueror's invitation to Jews from France to settle in England and establish a network of credit and trading functions. English Medieval Jewish communities originated from the Ashkenazic Jewish communities of Northern France, known as the Tsarfat. The earliest surviving record of Jews in Oxford is a reference to an incident in 1141. It reports that King Stephen torched the Oxford house of Aaron f. Isaac and threatened to burn down the rest of the Jewry if immediate funds (to support his ongoing civil war against his cousin Matilda) were not forthcoming (Manix 2004).

Little is known of the archaeology of the medieval Jewry in England (although see Hinton 2003), but, fortuitously, the exceptional survival of medieval property records in Oxford provided a unique opportunity to identify the physical presence of the medieval Oxford Jewry. In particular, the Oxford section of the Hundreds Roll, the kingdom-wide property survey undertaken by Edward 1 in 1278, was particularly detailed. This survey only survives for seven counties and, in most areas, towns were surveyed non-topographically, by landlord. However, almost every ward in Oxford was surveyed sequentially, street by street and house by house. This means the location of the Jewish community and, indeed, individual Jewish properties can be identified (Fig. 2; Manix 2004). The northern border of the Jewish area was formed by the west/east axis passing through the main crossroads, Carfax. To the west, this area comprised Great Bayly Street, which was dominated by butchers' stalls and stinking drains known as The Shambles. To the east, on the High Street, tanning and vellum-making stalls known as The Boucherie straddled the drains there. The main thoroughfare of the Jewry was Fish Street, occupied in the northern half by fishmonger stalls (Fig. 2). The presence of these malodorous workshops of the animal butchering and fish-mongering trades is most likely the reason the Oxford Jewry was able to inhabit what was an otherwise prime location in the city.

The main period of occupation of the Jewish quarter was the twelfth to late thirteenth century which was marked by periods of both crisis and consolidation. A Jewish synagogue was built by Copin of Worcester and a Jewish cemetery was established. However, during the reign of King John, brutal tallages meant the confiscation of some Jewish properties. Later, in the 1269 Provisions of the Jewry and the 1271 Mandate to the Jews, Jews were prohibited from taking any more property into bond or mortgage (Manix 2004).

One of the most substantial private houses in Oxford was Jacob's Hall, which fronted onto St Aldates (formerly Fish Street). This was owned by Jacob f. mag. Moses but the property was confiscated from his widow and heirs on his death in 1277, by the Queen (Eleanor of Castile) in a well-documented court battle. Within the boundary of Jacob's Hall was a property owned by Elekin f. Bassina, who was later hanged for real estate and tallage payment fraud. In 1279, the Queen confiscated this property and granted it to her cook, Henry Wade (Manix 2004).

The Jewry came to an end on 18th July 1290 when the Jews were expelled from England by Edward I and their goods and property confiscated by the Crown. By the fourteenth century, all Jewish properties in Oxford were in Christian ownership. With the exception of a few Spanish and Portuguese Sephardi individuals during the reign of Elizabeth, Jews would not be readmitted to England until the time of Oliver Cromwell (Manix 2004).

\section{Archaeological excavations at St. Aldates, Oxford}

Recent excavations by Oxford Archaeology (Teague et al. 2020), carried out at 114-19 St Aldates and 4-5 Queen Street, (the south-west side of Carfax), Oxford (Fig. 3), yielded archaeological remains dating from the middle/late Saxon period (phases 1 and 2) through to the early eighteenth to nineteenth century (phase 8 ). This included the medieval period (phase 3: late eleventh and twelfth centuries), the fourteenth and fifteenth centuries (phase 4), the late medieval period (phase 5: fifteenth to mid-sixteenth century), the midsixteenth and mid-seventeenth centuries (phase 6) and 


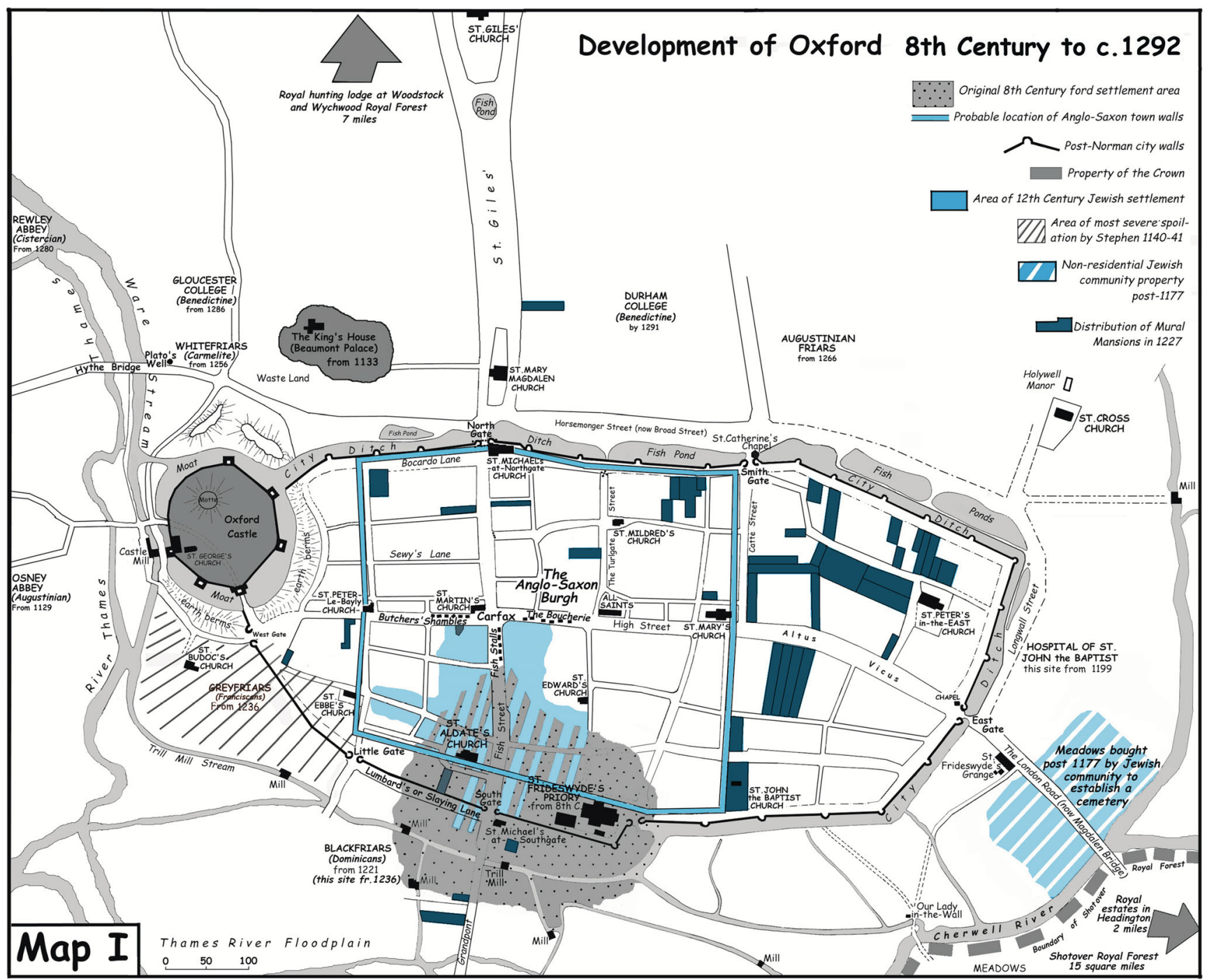

Fig. 1 Map showing the development of the city of Oxford from the 8th century to $c$. 1292, with the Jewish quarter shown in blue

evidence of phase 7 (mid-seventeenth to early eighteenth century).

As discussed, two of the four properties partly exposed by the area of excavation (in phase 3) were identified, through documentary evidence, as being in Jewish ownership during the late eleventh and twelfth centuries (Fig. 4). Both fronted onto St Aldates (formerly Fish Street), with one being Jacob's Hall, owned by Jacob f. mag. Moses, and the other a property owned by Elekin f. Bassina (Fig. 2). The other two properties were held by the Bishop of Lichfield and fronted onto Queen Street (formerly Butcher Row/Great Bailey).

Structure 3.1 appears to be set within the boundary of Jacob's Hall (Fig. 4). This structure, probably a latrine, comprised a rectangular shaft measuring $1.7 \times 1.3 \mathrm{~m}$ and about $1.1 \mathrm{~m}$ deep, lined with roughly squared limestone blocks bonded by a firm reddish brown sandy/gravel mortar. There was a pair of opposing putlog holes on its east and west walls near to its excavated depth, presumably to hold temporary supports during its construction. Its internal wall faces were rendered with a thin whitish mortar wash. Its basal fill (1101) comprised a thin greenish silty sand with lenses of charcoal that contained small amounts of mineralised concretions, potentially faecal waste. This structure is thought to be associated with a house of a wealthy individual, which contained a rich assemblage of twelfth- or early thirteenth-century pottery, animal bone and other domestic material. Also found in this area were postholes relating to a fence or other timber structure, while structure 3.2 belonged to a wall that divided two buildings, one extending to the north, the other to the south (and beyond the area of investigation). Rectangular holes and stone projections seen on the north face of the wall marked the position of a wooden floor. Ceramic building material suggests that buildings had tiled roofs with chimneys and (at least partially) tiled floors. This is consistent with the stone walls of structures 3.1 and 3.2, 


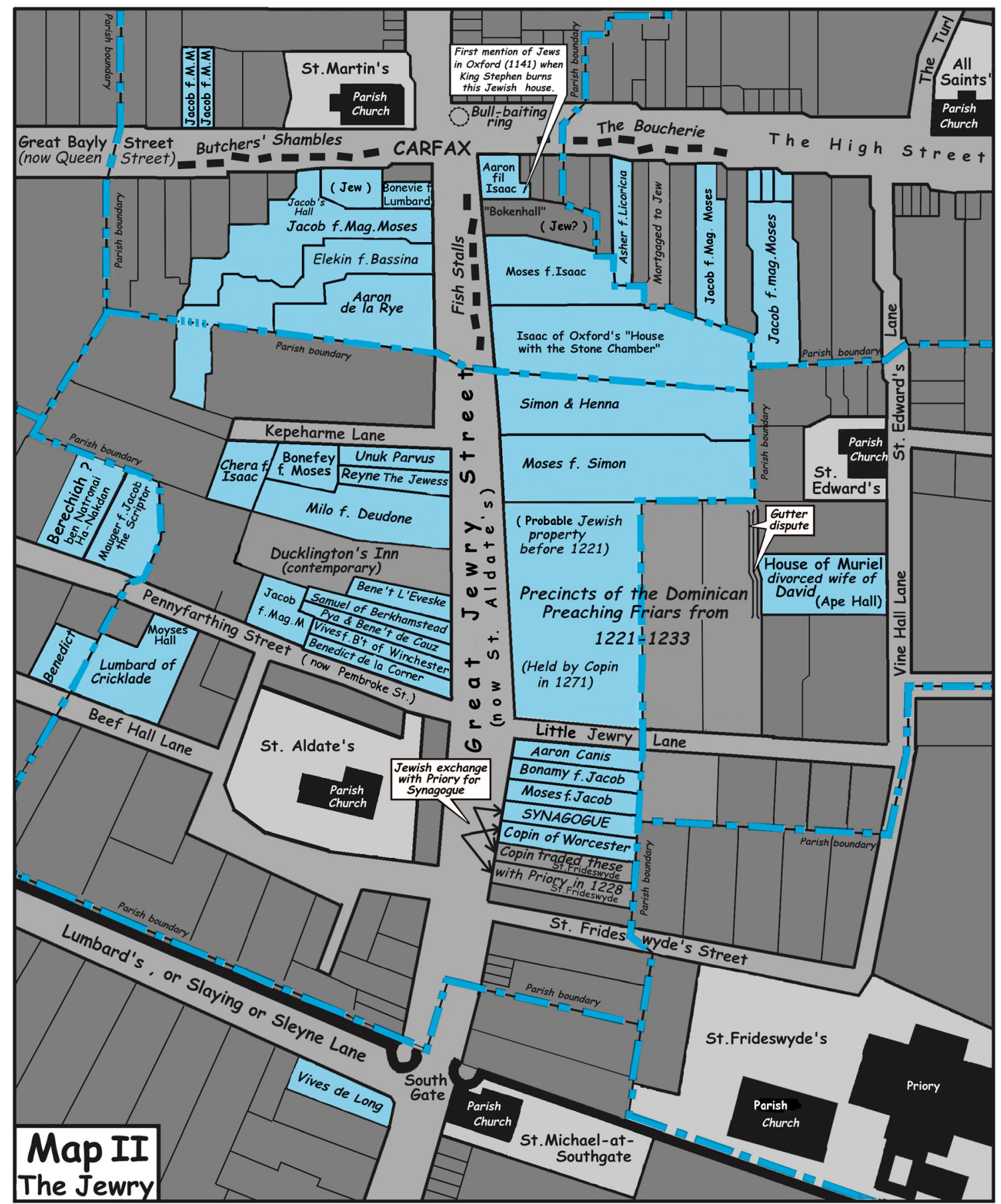

Fig. 2 Map of the medieval Jewish quarter in Oxford, showing the properties of Jacob f. mag. Moses and Elekin f. Bassina

which denote wealthy buildings (contrasting with the wooden buildings of earlier phases). It is in structure 3.1 that archaeological evidence consistent with Jewish inhabitation was found (Teague et al. 2020).

The presence of pottery and a faunal assemblage in these possible Jewish properties provided a unique opportunity to investigate whether a Jewish dietary 'signal' could be identified, using a combined organic residue and faunal approach.

\section{Organic residue analysis} and the identification of religious dietary practices

Organic residue analysis is most notably known for its contribution to elucidating diet and animal management strategies on a global scale (e.g. Copley et al. 2003; Craig et al. 2003; Copley et al. 2004b; Copley et al. 2005a, b, c; Evershed et al. 
Fig. 3 Location of St Aldates site, Oxford

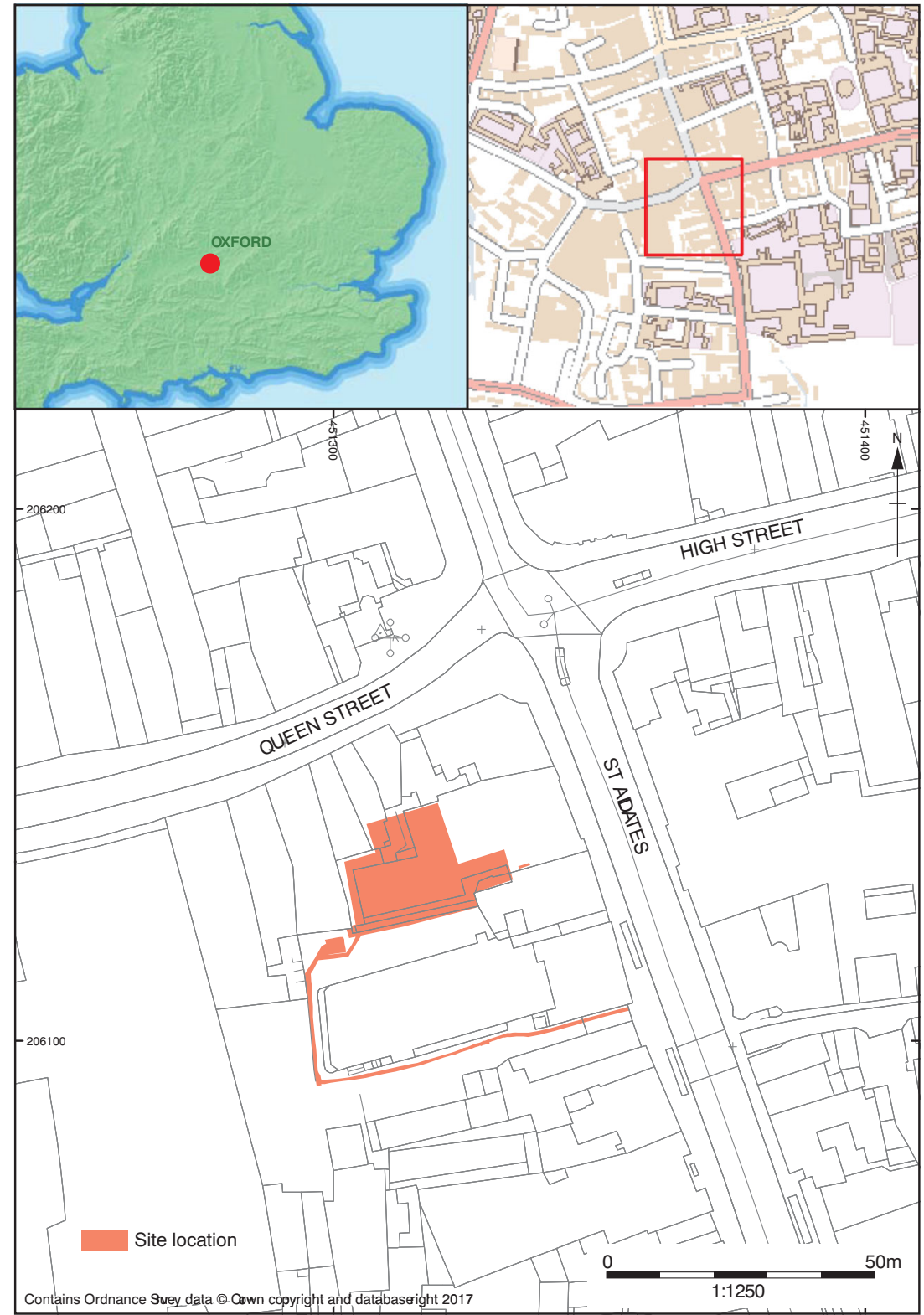

2008; Outram et al. 2009; Dunne et al. 2012; Cramp et al. 2014a, b; Heron et al. 2015; Smyth and Evershed 2015; Debono Spiteri et al. 2016; Dunne et al. 2017; Ethier et al. 2017; Mileto et al. 2017; Whelton et al. 2018). Employing these chemical analyses in the reconstruction of vessel use at sites worldwide has enabled the identification and separation of terrestrial animal fats (Evershed et al. 1997a; Mottram et al. 1999; Evershed et al. 2002), marine animal fats (Copley et al. 2004a; Craig et al. 2007; Cramp and Evershed 2014; Cramp et al. 2014b), plant waxes (Evershed et al. 1991; Dunne et al. 2016), beeswax (Evershed et al. 1997b; Roffet-Salque et al. 2015) and birch bark tar (Charters et al. 1993; Urem-Kotsou et al. 2002; Stacey et al. 2020). Particularly relevant are other applications which include the investigation of ritual beliefs and cultural practices (Roffet-Salque et al. 2017). For example, organic residue analysis of 'grave dust' found in Romano-British mortuary contexts found Boswellia spp. gum-resins (frankincense) and Pistacia spp. (mastic/terebinth) resins in Roman burials, suggesting the considerable ritual significance of these scented substances in the mortuary sphere (Brettell et al. 2014, 2015a, b).

However, to our knowledge, organic residue analysis has never been used to identify specific religious dietary practices, such as Judaism, despite its obvious potential. To this end, we carried out lipid analysis on ceramics from the medieval phases 3 and (early) 4, containing features thought to be associated with Jacob's Hall, a property belonging to the Jewish quarter. Pottery from the earlier Saxon phases 1 and 2 at the St Aldates site and ceramics from a contemporaneous (to the Jewish quarter phases 3 and 4) early Medieval site, the 


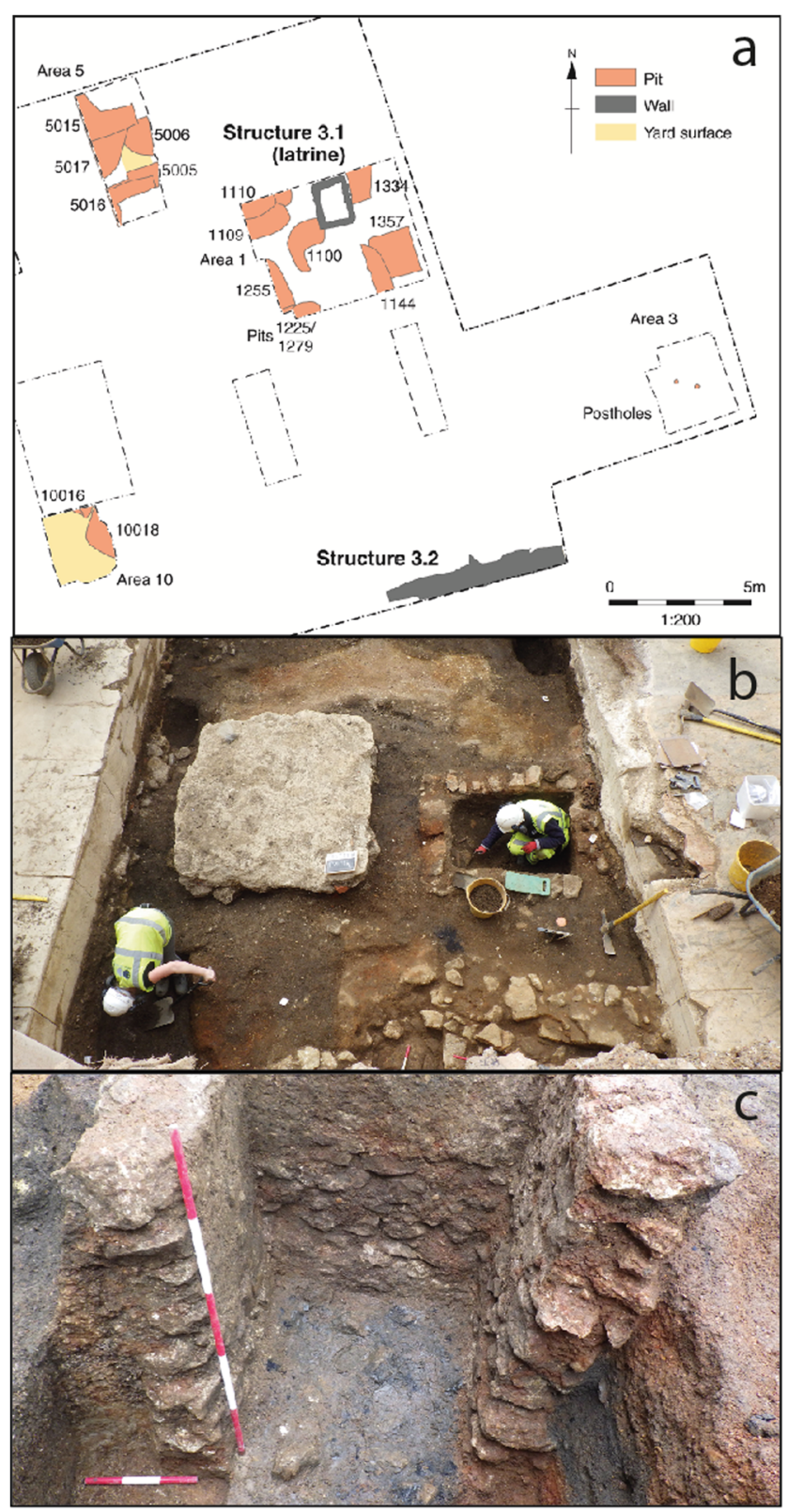

Fig. 4 a Plan of the late 11th/12th-century features, $\mathbf{b}$ view of the stonelined latrine, structure 3.1, with a later cellared structure in the foreground and $\mathbf{c}$ close-up of latrine structure 3.1, after removal of the south wall

Provosts's Garden, The Queen's College, Oxford, were also analysed to act as comparanda and examine possible differences or similarities between the assemblages. The Queen's College site, which is also located centrally in the historic core of Oxford, to the north of the High Street, lies within the eastern part of the late Saxon burh at Oxford. The site was potentially in use as early as the late ninth century, seeing an intensive period of occupation, possibly dating from the tenth century, and thought to be a domestic site (pre-college) largely confined between two possible plot boundaries, suggesting some degree of organisation (Teague and Brown 2020). These data were then correlated with the animal and fish bone assemblages from both phases at St Aldates and The Queen's College sites, highlighting the potential of faunal analysis in detecting observant Jewish populations.

\section{Material and methods}

\section{The archaeological pottery}

The St Aldates pottery assemblage comprised 2028 sherds with a total weight of $38,767 \mathrm{~g}$. The estimated vessel equivalent (EVE), by summation of surviving rim sherd circumference, was 24.57. It was recorded using the conventions of the Oxfordshire county type-series (Mellor 1994). The general range of pottery types is fairly typical of sites in Oxford, albeit with some exotica in the form of late Saxon and medieval imports. This is a pattern that has been noted in the past at other excavations in the St Aldates area of the city. Excavations in the late 1960s and early 1970s, centred around 79-87 St Aldates, produced an assemblage similar to this one (Durham 1977).

Potsherds analysed from phases 1 and 2 comprised Late Saxon Oxford Shelly ware ( $n=12$, late eighth to early eleventh century) and one St Neots ware sherd (AD 850-1200). The pottery analysed from phases 3 and 4 (Fig. 5) comprised mostly Medieval Oxford ware $(n=19$, AD 1075-1350) with two Early Brill coarseware sherds (AD 1180-1250) and one Cotswold-type ware (AD 975-1350). The Queens College pottery comprised Cotswold-type ware $(n=7)$ and Medieval Oxford ware $(n=12)$, the dominant locally produced ware in assemblages of this date.

It should be noted that none of the phase 3 ORA samples came from structure 3.1, but instead were taken from vessels recovered from area 1 pits. These were dominated by medieval Oxford ware and Cotswold-type ware, suggesting a date prior to the late twelfth century. However, their respective contexts were in the upper part of the sequence of filling and contained no pig bones, eel bones or marine shell, and may belong to episodes of levelling related to the construction of the property (Jacob's Hall?) represented by structure 3.1.

\section{Results}

A total of 70 sherds were sampled, 16 from the preceding St Aldates phases 1 and 2, 28 from the Jewish Quarter phases 3 and 4 and a further 26 sherds from The Queen's College site (which is contemporaneous to the Jewish Quarter phase), to act as a direct comparison (Tables 1 and 2). Of these, 8 potsherds from the St Aldates phases 1 and 2 were published previously (Craig-Atkins et al. 2020).

The lipid recovery rate from both sites was excellent at $77 \%$ overall. The mean lipid concentration from the sherds 


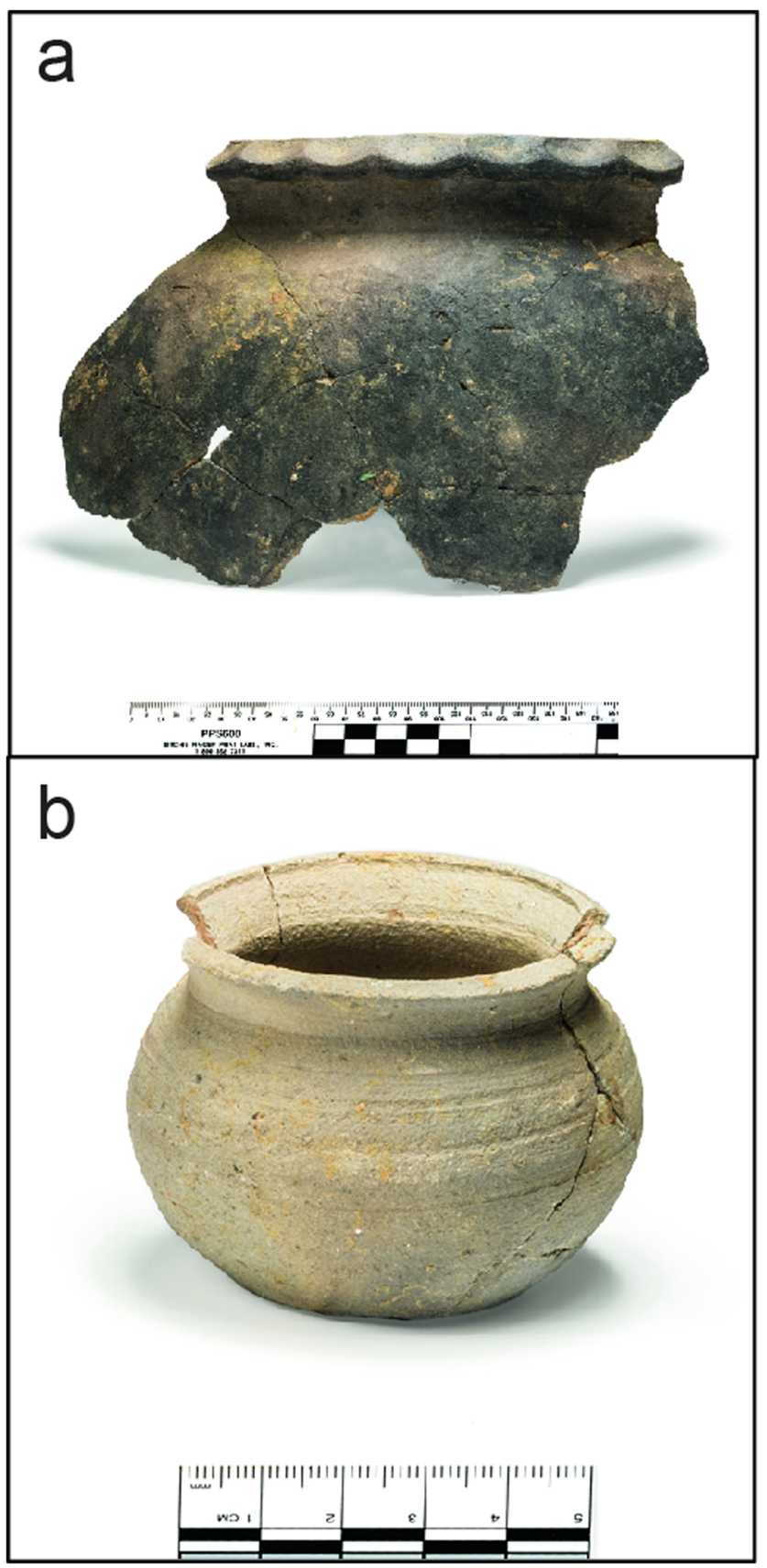

Fig. 5 a Jar in Medieval Oxford ware, probably used as a cooking-pot and dated to the late 11th or 12th century and $\mathbf{b}$ near-complete miniature jar in Early Brill coarseware from structure 3.1

(Table 2) was $13.2 \mathrm{mg} \mathrm{g}^{-1}$, with a maximum lipid concentration of $93.4 \mathrm{mg} \mathrm{g}^{-1}$ (OXF043). Many of the potsherds contained very high concentrations of lipids (e.g. OXF003, $42.0 \mathrm{mg} \mathrm{g}^{-1}$; OXF021, $45.5 \mathrm{mg} \mathrm{g}^{-}$1; OXF025, $36.4 \mathrm{mg} \mathrm{g}^{-1}$; OXF045, 64.5 $\mathrm{mg} \mathrm{g}^{-1}$; OXF052, $42.3 \mathrm{mg} \mathrm{g}^{-1}$ ), demonstrating excellent preservation. This likely indicates that these were vessels which were subjected to sustained use in the processing of high lipid-yielding commodities, presumably as cooking pots. However, it should be noted that these sherds have spent far less time in the burial environment than prehistoric potsherds (up to several thousands of years), and thus, there is far less time for degradation processes to occur.

To date, analysis of the total lipid extracts (TLEs, $n=70$ ) from the two Oxford sites, using GC and GC-MS, demonstrated that 54 sherds contained sufficient concentrations $\left(>5 \mu \mathrm{g} \mathrm{g}^{-1}\right.$ ) of lipids that can be reliably interpreted (Evershed 2008). These extracts comprised lipid profiles which demonstrated free fatty acids, palmitic $\left(\mathrm{C}_{16}\right)$ and stearic $\left(\mathrm{C}_{18}\right)$, typical of a degraded animal fat (Fig. 6a-c), were the most abundant components (e.g. Evershed et al. 1997a; Berstan et al. 2008).

Significantly, in vessels OXF019 (Fig. 6b), OXF041 and OXF051, odd carbon number ketones were present $\left(\mathrm{C}_{31: 0}\right.$, $\mathrm{C}_{33: 0}$ and $\mathrm{C}_{35: 0}$, blue triangles). Experimental analysis has shown these ketones, found in a monomodal distribution, originate from the pyrolysis of acyl lipids and ketonic decarboxylation reactions which occur in unglazed ceramic vessels during cooking, when the temperature exceeds $300{ }^{\circ} \mathrm{C}$. These ketones are thought to accumulate gradually with repeated use (Evershed et al. 1995; Raven et al. 1997), confirming these particular vessels were used as cooking pots.

GC-C-IRMS analyses were carried out on 54 samples (Table 2 and Fig. 7) to determine the $\delta^{13} \mathrm{C}$ values of the major fatty acids, $\mathrm{C}_{16: 0}$ and $\mathrm{C}_{18: 0}$, which reflect their biosynthetic and dietary origin, allowing non-ruminant and ruminant adipose and ruminant dairy products to be distinguished (Dudd and Evershed 1998; Copley et al. 2003; Dunne et al. 2012). In the Queen's College assemblage $(n=19)$, vessel numbers OXF001, OXF003, OXF006 and OXF011, OXF014, OXF050, OXF054, OXF055 and OXF058 plot within, or just outside, the reference ellipse for ruminant adipose fats (Fig. $7 \mathrm{e}$ ), suggesting these vessels were solely used to process carcass products from cattle (Bos taurus taurus), sheep (Ovis aries) and goat (Capra hircus. The remaining vessels, OXF007, OXF008, OXF010, OXF012, OXF013, OXF051, OXF052, OXF053, OXF057 and OXF059, plot between the ruminant adipose and non-ruminant adipose ellipses indicative of some mixing of animal products from ruminants (cattle, sheep and goat) and non-ruminants (pig, Sus scrofa domesticus), in varying degrees. Interestingly, there is no indication of dairy product processing at The Queen's College site.

The $\delta^{13} \mathrm{C}$ values of the lipid extracts from St Aldates phases 1 and $2(n=13)$ confirm that six vessels, OXF033, OXF043, SN33, SN34, SN35 and SN39, plot within, or just outside, the reference ellipse for ruminant adipose fats (Fig. 7a). The remaining vessels, OXF032, OXF041, OXF042, SN31, SN32 and $\mathrm{SN} 37$, plot between the ruminant adipose and nonruminant adipose ellipses, again indicative of some mixing of ruminant and non-ruminant animal products. One vessel, SN40, plots within the dairy product ellipse (Fig. 7a), confirming it was used solely to process dairy products, such as milk, cream, butter or cheese. 
Table 1 Site, pottery ware typeseries (according to the conventions of the Oxfordshire County type-series), ware type and number of sherds from the late eleventh to twelfth century (phases 1 and 2) and from the thirteenth to fourteenth century (phases 3 and 4)

\begin{tabular}{lllll}
\hline Site & $\begin{array}{l}\text { Ware type- } \\
\text { series }\end{array}$ & Ware type & $\begin{array}{l}\text { 11th/12th C } \\
\text { (phases 1 and 2) }\end{array}$ & $\begin{array}{l}\text { 13th/14th C } \\
\text { (phase 3) }\end{array}$ \\
\hline The Queen's College & OXAC & Costwold ware & 6 & 3 \\
& OXY & Medieval Oxford ware & 1 & 15 \\
& OXBF & Kennet Valley ware & - & 1 \\
St. Aldates & OXAC & Costwold ware & 1 & 1 \\
& OXY & Medieval Oxford ware & 14 & 10 \\
& OXB & Late Saxon Oxford Shelly ware & 15 & - \\
& OXAW & Early Brill coarseware & 2 & - \\
& OXR & St Neots ware & 1 & - \\
& & 40 & 30
\end{tabular}

All vessels, save OXF021, OXF036 and OXF039, from phases 3 and 4, St Aldates, plot within, or on the border of the reference ellipse for ruminant adipose fats $(n=19$, total, Fig. 7c). These three vessels plot just outside the reference ellipse. These data suggest the majority $(n=16)$ of the vessels were solely used to process carcass products from cattle, sheep or goat. Three vessels plot just outside which might suggest some mixing with animal fats of a non-ruminant origin, although likely in very minor quantities. These may be porcine products (although pig bones are not common in phase 3 ), but, significantly, bird bones account for a third of the faunal assemblage in this period, so these data more likely suggest the processing of bird products with the ruminant products. One vessel, OXF029, plots within the dairy product ellipse, confirming it was used solely to process dairy products, such as milk, cream, butter and cheese.

Lipid residue results for the early St Aldates phases 1 and 2 and the later St Aldates phases 3 and 4 show that two lipid residues from phases 1 and 2 (SN39 and SN40, Fig. 7b) and one from phases 3 and 4, OXF029, Fig. 7d) plot in the ruminant dairy region with $\Delta^{13} \mathrm{C}$ values of $-6.6 \%$ and $-3.4 \%$ and $-5.2 \%$, respectively, confirming the use of secondary products, such as milk, butter and cheese, in both phases, albeit at a very minor level. The $\Delta^{13} \mathrm{C}$ value of $-3.4 \%$ for vessel SN40 suggests some mixing of ruminant carcass and dairy products may have occurred in this vessel. No dairy product processing was identified at the Queen's College site (Fig. 7f). All lipid residues at Queen's College plot within the ruminant adipose region, save OXF013 which plots in the non-ruminant region. Significantly, all other vessels from St Aldates phases plot firmly within the ruminant carcass products region.

The presence of fish bones and marine shells at the site suggests that fish may have played a role in medieval diet. Consequently, 21 residues from both sites and phases were analysed by GC-MS in SIM mode to check for the presence of aquatic or freshwater biomarkers, which would denote the processing of shellfish/crustaceans, fish and marine mammals. These comprise long-chain $\omega$-(o-alkylphenyl) alkanoic acids
(APAAs) and vicinal dihydroxy acid (DHYAs) which originate from the degradation of poly- and monounsaturated fatty acids found in marine or freshwater fats and oils and are routinely used to detect marine product processing (Hansel et al. 2004; Craig et al. 2007; Hansel and Evershed 2009; Cramp and Evershed 2014). The only evidence for aquatic product processing came from six vessels which yielded the $\mathrm{C}_{18}$ APAA and $\mathrm{C}_{20}$ APAA, and although these cannot be regarded as evidence for fish processing on their own, some aquatic input to the vessels cannot be discounted. It should be noted that fish could also have been prepared through drying, pickling, salting or smoking or have been cooked by other methods, such as grilling on open fires.

\section{St Aldates animal bone assemblage-materials and methods}

In all, 5072 animal bone specimens were recovered from the site and assessed according to current guidelines (Baker and Worley 2014, Tables S2 and S3). A subset was selected for analysis targeting the Saxon layers of the site (phases 1 and 2) as well as cesspits from phases 3 and 7. This selected assemblage consisted of 798 specimens, including 131 recovered through environmental sampling, and was recorded using a diagnostic zone system (Cohen and Serjeantson 1996; Serjeantson 1996).

\section{St Aldates animal bone assemblage phases 1 and 2}

The Saxon animal bone assemblage was dominated by the three principal domesticates (online resource Table 1)-domestic cattle (approximately 40\%), caprine (40\%, sheep and/ or goat) and pig (20\%). These proportions are typical of assemblages found in medieval towns (Albarella 2006). Of these, domestic cattle was the most common species by NISP (Number of Identified Specimens). No obvious bias to any particular body part was observed among these specimens, with head, limb and torso elements all being present. 


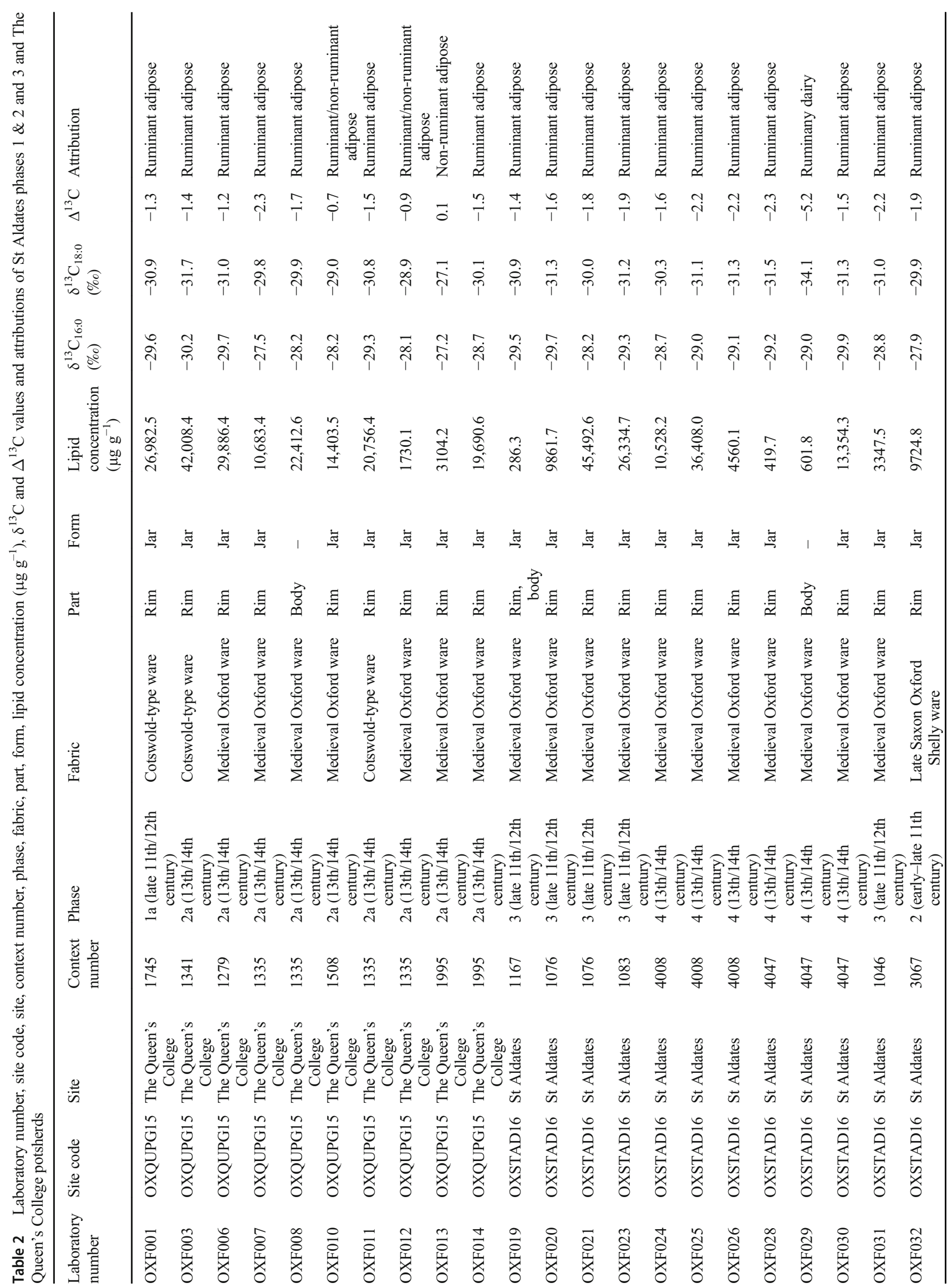




\begin{tabular}{|c|c|c|c|c|c|c|c|c|c|c|c|c|c|c|c|c|c|c|c|c|c|c|c|}
\hline $\begin{array}{l}\text { 营 } \\
\text { 营 } \\
\text { 甚 }\end{array}$ & 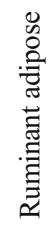 & 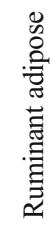 & 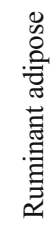 & 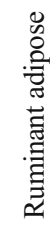 & 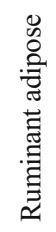 & 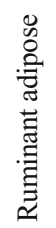 & 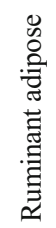 & 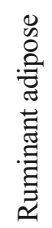 & 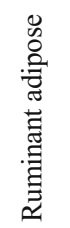 & 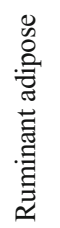 & 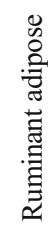 & 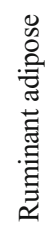 & 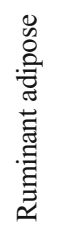 & 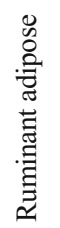 & 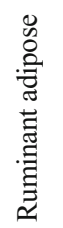 & 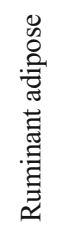 & 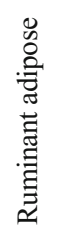 & 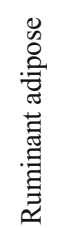 & 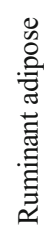 & 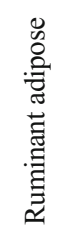 & 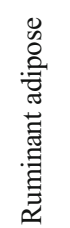 & 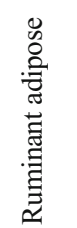 & 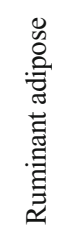 \\
\hline$\stackrel{\cup}{\triangleleft}$ & $\stackrel{\infty}{i}$ & $\stackrel{\infty}{i}$ & $\stackrel{\infty}{i}$ & $\bar{i}$ & $\tilde{i}$ & $\stackrel{\leftrightarrow}{i}$ & $\stackrel{\tilde{T}}{i}$ & $\stackrel{+}{i}$ & $\stackrel{\uparrow}{i}$ & $\stackrel{\infty}{i}$ & $\vec{i}$ & $\stackrel{0}{i}$ & $\stackrel{0}{i}$ & $\vec{i}$ & $\stackrel{+}{i}$ & $\stackrel{0}{i}$ & $\stackrel{+}{i}$ & $\hat{T}$ & $\stackrel{+}{i}$ & $\vec{i}$ & $\stackrel{9}{i}$ & $\stackrel{i}{i}$ & $\stackrel{\infty}{i}$ \\
\hline$\bigcup_{\substack{\infty \\
\infty}}^{\stackrel{0}{\infty}}$ & $\frac{\sim}{\tilde{T}}$ & $\stackrel{\infty}{\stackrel{0}{0}}$ & $\stackrel{\stackrel{\oplus}{p}}{p}$ & ते & $\stackrel{\circ}{\vec{p}}$ & $\stackrel{\dot{p}}{\text { d. }}$ & $\hat{\dot{p}}$ & $\stackrel{\infty}{\stackrel{i}{i}}$ & חิ่ & $\stackrel{\circ}{\stackrel{\oplus}{i}}$ & $\stackrel{\circ}{\dot{p}}$ & $\stackrel{0}{\stackrel{0}{0}}$ & ஓे & $\stackrel{\infty}{\stackrel{0}{0}}$ & ळे & $\frac{m}{p}$ & थิ & $\hat{\hat{i}}$ & 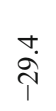 & 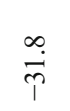 & $\stackrel{\infty}{\stackrel{0}{0}}$ & 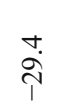 & $\begin{array}{l}\stackrel{\leftrightarrow}{\circ} \\
\stackrel{i}{1}\end{array}$ \\
\hline 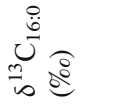 & $\stackrel{\text { }}{\hat{T}}$ & $\begin{array}{c}\hat{\infty} \\
\stackrel{i}{i}\end{array}$ & ఫัे & $\begin{array}{l}\infty \\
\infty \\
\infty\end{array}$ & $\begin{array}{l}\infty \\
\infty \\
\infty \\
\uparrow\end{array}$ & 0 & $\begin{array}{l}+\dot{D} \\
\stackrel{\oplus}{T}\end{array}$ & 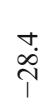 & $\stackrel{\hat{\uparrow}}{\hat{\uparrow}}$ & $\underset{\infty}{\stackrel{\infty}{1}}$ & $\begin{array}{l}\hat{\infty} \\
\stackrel{\uparrow}{T}\end{array}$ & $\overrightarrow{\widehat{i}}$ & तั & $\begin{array}{l}\infty \\
\infty \\
\stackrel{i}{\uparrow}\end{array}$ & $\begin{array}{l}n \\
\infty \\
i \\
i\end{array}$ & $\stackrel{\infty}{\stackrel{\hat{\imath}}{0}}$ & $\begin{array}{l}\vec{\infty} \\
\vec{\uparrow}\end{array}$ & $\stackrel{\overrightarrow{\hat{T}}}{\hat{i}}$ & $\begin{array}{l}0 \\
\infty \\
\stackrel{i}{\uparrow}\end{array}$ & $\overrightarrow{\hat{i}}$ & $\begin{array}{l}\stackrel{\partial}{\hat{T}} \\
\hat{\uparrow}\end{array}$ & $\stackrel{?}{\hat{i}}$ & $\begin{array}{l}0 \\
\dot{0} \\
\stackrel{\uparrow}{\Lambda}\end{array}$ \\
\hline 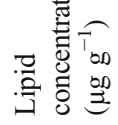 & 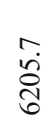 & $\underset{\stackrel{\vec{J}}{n}}{\stackrel{+}{n}}$ & $\underset{\sim}{\stackrel{0}{\sim}}$ & 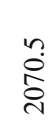 & $\begin{array}{l}n \\
\infty \\
\infty \\
6 \\
6\end{array}$ & $\stackrel{\vec{m}}{\sim}$ & $\begin{array}{l}0 \\
\infty \\
\infty\end{array}$ & तે & $\begin{array}{l}0 \\
\dot{8} \\
\dot{0} \\
\dot{n}\end{array}$ & 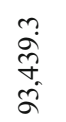 & $\begin{array}{l}\hat{\dot{O}} \\
\stackrel{\infty}{+} \\
\dot{0}\end{array}$ & 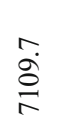 & 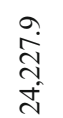 & 悹 & 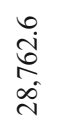 & 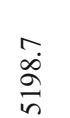 & $\begin{array}{l}\stackrel{0}{.} \\
\stackrel{\text { iे }}{ }\end{array}$ & $\begin{array}{l}n \\
\stackrel{n}{n} \\
\tilde{n} \\
\tilde{f}\end{array}$ & 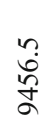 & 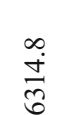 & $\begin{array}{l}n \\
n \\
n \\
n\end{array}$ & 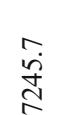 & बे \\
\hline 芳 & 离 & 总 & 点 & 点 & 点 & $\exists$ & 离 & ప్ & : & 离 & ప్ & 离 & 莺 & 芯 & 节 & 点 & $\overrightarrow{0}$ & : & छี & 宓 & 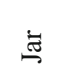 & ప్ & 点 \\
\hline 言 & 直 & 具 & 表 & 貝 & 直 & 表 & 具 & 声 & 直 & 具 & 貝 & 貝 & 责 & 直 & 貝 & 具 & 表 & 貝 & 昰 & 貝 & 昰 & 奉 & 貝 \\
\hline 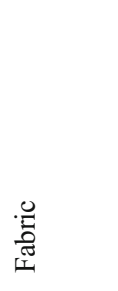 & 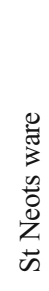 & 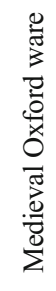 & 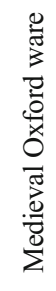 & 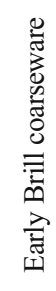 & 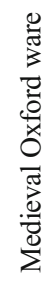 & 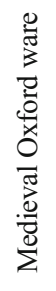 & 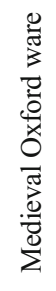 & 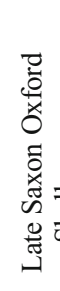 & $\overrightarrow{\tilde{c}}$ & 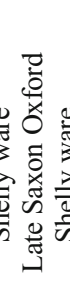 & 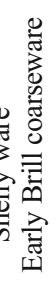 & 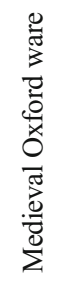 & 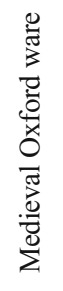 & 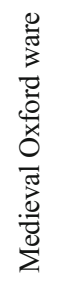 & 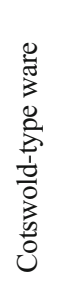 & 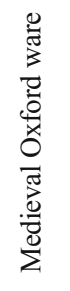 & 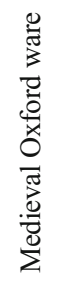 & $\begin{array}{l}0 \\
0 \\
3 \\
0 \\
0 \\
0 \\
0 \\
0 \\
0 \\
0 \\
0 \\
0 \\
0 \\
0 \\
0\end{array}$ & 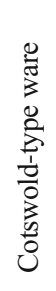 & 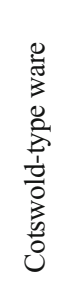 & $\begin{array}{l}0 \\
0 \\
3 \\
0 \\
0 \\
0 \\
0 \\
0 \\
0 \\
0 \\
0 \\
0 \\
0 \\
0 \\
0\end{array}$ & 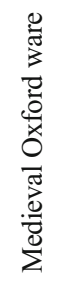 & 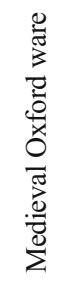 \\
\hline 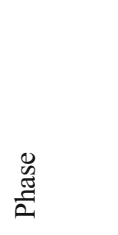 & 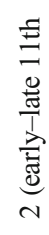 & & & ్ㅗ & $\stackrel{\Xi}{\Xi}$ & $\subsetneq$ & 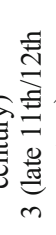 & 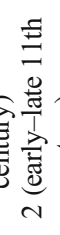 & $\Xi$ & $\begin{array}{l}\text { 志 } \\
\text { 总 }\end{array}$ & 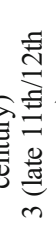 & & $\checkmark$ & & & $\overrightarrow{\widetilde{U}}$ & & & $\stackrel{\Xi}{\Xi}$ & $\stackrel{\Xi}{\leftrightarrows}$ & 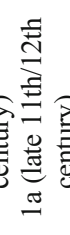 & 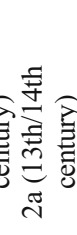 & \\
\hline 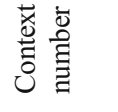 & $\underset{\Xi}{\stackrel{\Delta}{\Xi}}$ & $\stackrel{\bullet}{I}$ & ̊ิ & $\stackrel{\otimes}{\circ}$ & $\stackrel{\Xi}{ٍ}$ & $\stackrel{\Xi}{\beth}$ & 응 & 命 & ల్లి & 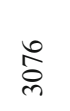 & $\stackrel{8}{\circ}$ & 字 & 字 & 字 & 字 & $\stackrel{2}{=}$ & $\stackrel{2}{\Xi}$ & $\stackrel{8}{=}$ & \& & \& & \& & $\stackrel{\text { 尺े }}{1}$ & $\frac{n}{n}$ \\
\hline$\stackrel{\frac{9}{\omega}}{\tilde{n}}$ & 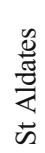 & 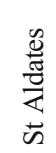 & 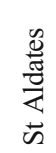 & 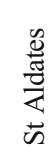 & 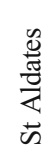 & 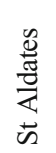 & 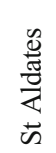 & 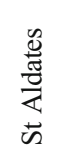 & 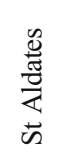 & 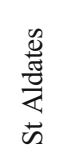 & 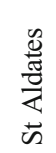 & 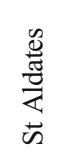 & 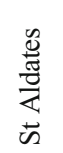 & 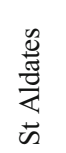 & 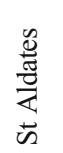 & 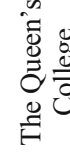 & & & & $\stackrel{g}{E}$ & & 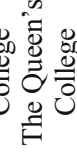 & \\
\hline 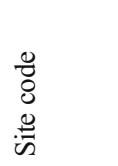 & 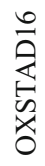 & 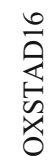 & 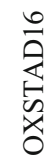 & 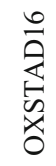 & 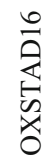 & 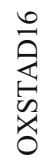 & 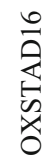 & 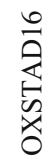 & 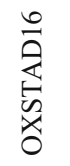 & 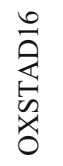 & 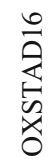 & 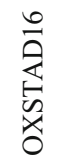 & 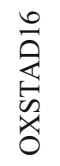 & 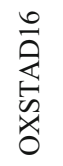 & 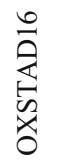 & $\begin{array}{l}n \\
0 \\
0 \\
\vdots \\
0 \\
0 \\
0\end{array}$ & $\begin{array}{l}n \\
0 \\
0 \\
\vdots \\
0 \\
0 \\
0\end{array}$ & $\begin{array}{l}n \\
0 \\
\vdots \\
0 \\
0 \\
0 \\
0\end{array}$ & $\begin{array}{l}n \\
0 \\
0 \\
\vdots \\
0 \\
x \\
0\end{array}$ & $\begin{array}{l}n \\
0 \\
0 \\
\vdots \\
0 \\
x \\
0\end{array}$ & $\begin{array}{l}n \\
0 \\
0 \\
\vdots \\
0 \\
⿱ 亠 乂 \\
0\end{array}$ & $\begin{array}{l}n \\
0 \\
\vdots \\
0 \\
\ddot{x} \\
0\end{array}$ & 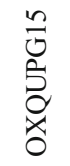 \\
\hline 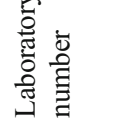 & 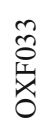 & 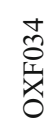 & 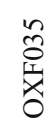 & 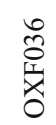 & 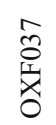 & లి & 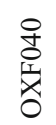 & 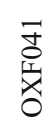 & 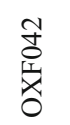 & $\begin{array}{l}\text { ?a } \\
\text { 㐎 } \\
0\end{array}$ & 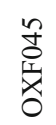 & 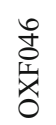 & 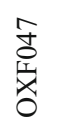 & 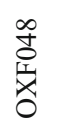 & 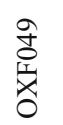 & 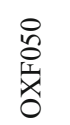 & $\begin{array}{l}\vec{n} \\
\text { 莣 } \\
0\end{array}$ & 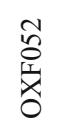 & 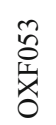 & 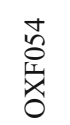 & $\begin{array}{l}n \\
\tilde{\alpha} \\
\text { 至 } \\
0\end{array}$ & $\begin{array}{l}\hat{n} \\
0 \\
\text { 齐 } \\
0\end{array}$ & $\begin{array}{l}\infty \\
2 \\
0 \\
\vdots \\
0 \\
0 \\
0\end{array}$ \\
\hline
\end{tabular}


Butchery consisted exclusively of chopmarks; of nine specimens observed with chopmarks, eight were axial chops. Four of these specimens with axial chops were humeri and the ninth specimen was also a humerus, with an oblique chop through the proximal end and possible signs of helical fracture. Two other specimens showed signs of helical fracture as well and, taken together with the axial chops through bones, it suggests that, whether due to taste or necessity, marrow fat formed a regular part of the diet of the site's inhabitants. Cutmarks were observed on five large mammal ribs from this phase, while six vertebrae had been chopped through, three obliquely and three axially, suggesting that more concern was paid to meat portion size than to anatomy. Although horse (Equus caballus) was observed in the assemblage, it was rare, with just one specimen each in phases 1 and 2. Unfortunately, the sample size was too small to offer meaningful insight into the age profile of any of the animals in the site, although it is possible to state that both young and old individuals were present. Sheep, but not goat, were also present with more oblique chopmarks among the caprine bones (four of seven specimens) but axial chopmarks (two) and a cutmark were also present, as were helical fractures. A foetal/neonatal metacarpal was identified, suggesting that breeding (or, at least, housing) of stock was taking place on or near the site. Butchery marks were rarer on the pig bones but these were far more likely to be unfused epiphyseally, suggesting a mainly young population. Since pigs have little economic use other than their meat, and reach slaughter weight before being skeletally mature, this is not surprising.

Poultry (domestic fowl Gallus gallus and goose Anser anser) were present in small numbers, and although wild species are represented in the assemblage by both red deer (Cervus elaphus) and roe deer (Capreolus capreolus), it is possible these represent craft activity.

\section{St Aldates animal bone assemblage phase 3 (Jewish phase)}

All the material analysed from phase 3 came from a single feature, structure 3.1, the latrine thought to be associated with Jacob's Hall within Oxford's Jewry (online resource Table 1). The faunal assemblage from this feature was remarkable for two reasons - the complete absence of any pig specimens and the dominance of kosher (permitted) birds, the domestic fowl and the goose, with 136 birds identified in phase 3 , in contrast to 37 domesticated animals (by NISP, online resource, Table 1). Interestingly, goose remains were more common than those of domestic cattle. Material recovered through environmental samples suggests that this pattern may be even more dramatic than might appear from the hand-recovered assemblage. The high proportion of bird bones recovered from the site, in particular, is exceptional and demands comparison not only with other British sites, including those from Oxford, of this period but also with sites in Europe where 


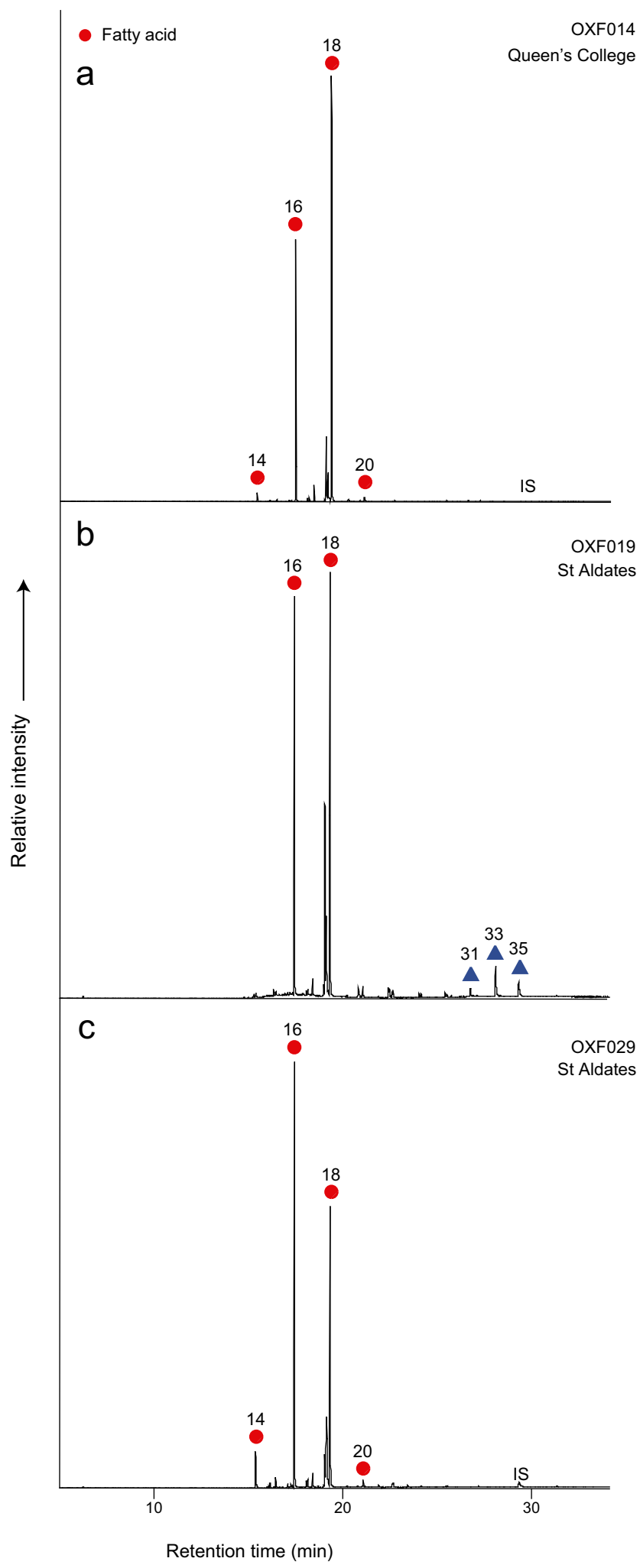

Fig. 6 Partial gas chromatograms of trimethylsilylated FAMEs showing typical degraded animal fat lipid profiles from vessels OXF014, OXF019 and OXF029, from The Queen's College and St. Aldates sites. Red circles, $n$-alkanoic acids (fatty acids, FA); blue triangles, mid-chain ketones, IS, internal standard, $\mathrm{C}_{34} n$-tetratriacontane. Number denotes carbon chain length zooarchaeological investigations into medieval Jewries have been carried out (see "Discussion"). An elite or high-status diet could also be considered although this seems unlikely as, although the consumption of birds in aristocratic and ecclesiastical medieval households is well-documented, they generally only make up c. $10 \%$ of meat consumed overall (Dyer 1998; Stone 2006).

Furthermore, the decrease in cattle bones on the site at this time may relate to the terefah (unpermitted) status of the hindquarters of these animals but it should be noted that the recording methods adopted for the assemblage preclude this kind of analysis.

Lesions consistent with osteochondrosis were present on some of the domestic cattle bones, but this is a relatively benign condition which would not have caused the animal any discomfort in life and so people would be unlikely to suspect the condition (Sewell 2010). Among the twenty-one caprine specimens recovered from this feature were five foetal or neonatal specimens recovered from context 1071. These may represent an ABG (Associated Bone Group) and include left and right, hind- and fore-limbs. Being small it is reasonable to suspect that other bones of the individual may have been missed. It is not clear how such an individual would end up in this feature were it simply stillborn and it may be that it represents a delicacy. Eight of the domestic fowl bones were also from juvenile individuals and one adult specimen came from a male individual. It is possible that the juvenile specimens also come from males since they would not be able to lay eggs and it is not necessary to keep male and female fowl in a fifty/fifty ratio for a viable flock.

\section{Animal bone assemblage from The Queen's College}

The late ninth- to eleventh-century animal bone assemblage from The Queen's College site yielded an assemblage dominated by sheep and/or goat. Around half as many domestic cattle specimens were present compared with caprine, and a little more than half as many pig as domestic cattle. Domestic fowl also made a substantial contribution to the assemblage. The dramatic change in species composition seen at St Aldates in the later phases is not seen at The Queen's College site with the proportion of species from twelfth- to thirteenth-century contexts being broadly similar to those from the earlier phases at the site discussed above.

\section{Fish and marine shell at St Aldates}

A total of 273 fragments of marine shell, weighing 3034 g, were recovered by hand from the excavations, with an additional $73 \mathrm{~g}$ of shell extracted from sieved soil sample residues (online resource Table 2). The material appears to comprise exclusively valves of European flat oyster (Ostrea edulis) in variable condition and size, although lacking very large 

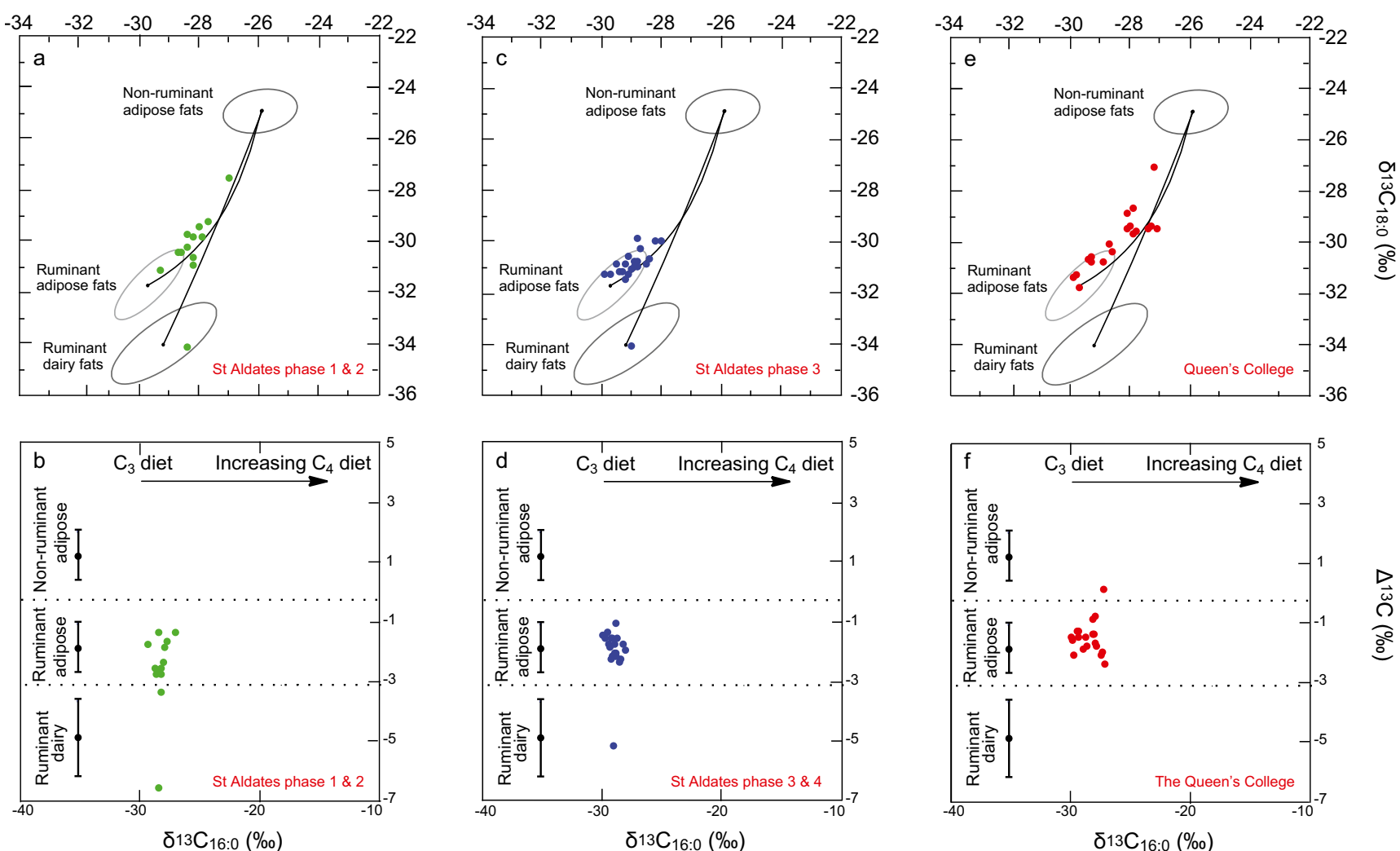

Fig. 7 Graphs showing a, c and $\mathbf{e} \delta^{13} \mathrm{C}$ values for the $\mathrm{C}_{16: 0}$ and $\mathrm{C}_{18: 0}$ fatty acids for archaeological fats extracted from St Aldates ceramics phases 1 and 2, St Aldates ceramics phases 3 and 4 and Queen's College, respectively. The three fields correspond to the $P=0.684$ confidence ellipses for animals raised on a strict $\mathrm{C}_{3}$ diet in Britain (Copley et al. 2003). Each data point represents an individual vessel. b, $\mathbf{d}$ and $\mathbf{f}$ show the $\Delta^{13} \mathrm{C}\left(\delta^{13} \mathrm{C}_{18: 0}-\delta^{13} \mathrm{C}_{16: 0}\right)$ values from the same potsherds. The

examples. Oyster shells are a common find in medieval and post-medieval assemblages, and the assemblage from $\mathrm{St}$ Aldates confirms that they must have been regularly eaten, although not in large amounts in the properties relating to this site. Only three fragments come from deposits provisionally phased as late Saxon (phase 1) and ten contexts phased as early to late eleventh century (phase 2). Furthermore, of the 89 fragments of marine shell recovered from phase 3 deposits, just one came from structure 3.1.

Fish remains were found in cesspit fill 1080, from structure 3.1 , and the sample from that fill included only a single herring vertebra and indeterminate fin rays. Since pig bones were also absent from the fills of this structure, it may be directly associated with the Jewish occupation and so it can perhaps be tentatively suggested that the Jewish occupants ate little fish. However, this supposition has to be qualified because of the small number of soil samples that were processed and, in particular, from deposits dating to the later part of the twelfth century. Interestingly, eel bones were recovered from phase 2 deposits, and from phase 4 , the thirteenth- to fourteenthcentury layer (10013) in area 10 but were absent from phase 3. This may be significant in that eels are not kosher as they do ranges shown here represent the mean \pm 1 s.d. of the $\Delta^{13} \mathrm{C}$ values for a global database comprising modern reference animal fats from Africa (Dunne et al. 2012), the UK (animals raised on a pure $C_{3}$ diet) (Dudd and Evershed 1998), Kazakhstan (Outram et al. 2009), Switzerland (Spangenberg et al. 2006) and the Near East (Gregg et al. 2009) published elsewhere.

not have scales, following Leviticus 11:9, and would thus have been avoided by the Jewish inhabitants of the site.

Significantly, the fish assemblage at The Queen's College site, in both phases, late ninth to eleventh century and twelfth to thirteenth century, yielded herring and eel, together with other species such as plaice, haddock and whiting. Marine shell, mostly common/European oyster and mussel (mainly Mytilus edulis), were recovered largely from medieval and post-medieval pit fills. As noted, eel and shellfish are not kosher.

\section{Discussion}

Studies of food and ethnic identity often focus on Jewish and Islamic groups, particularly in relation to the taboo on eating pork, and exploring whether the archaeological record can identify such religious dietary practices. Indeed, recent studies have successfully used combined zooarchaeological and stable carbon $\left(\delta^{13} \mathrm{C}\right)$ and nitrogen $\left(\delta^{15} \mathrm{~N}\right)$ isotopic analysis of bone collagen to investigate diet in Islamic communities (e.g. Alexander et al. 2015; Grau-Sologestoa 2017; Toso 
et al. 2019). Faunal assemblages from archaeological sites provide valuable information on how animals were managed, butchered, consumed and traded in antiquity, and specific features of faunal assemblages, such as species consumed, anatomical representation and butchery practices, could, in theory, be used to distinguish between religious identities, including observant Jews, Muslims and Christians. For example, although both Jewish and Muslim faiths prohibit the consumption of pork, Jews are more restrictive in terms of other species, such as horses, rabbits and molluscs, which are also forbidden. In contrast, Muslims can consume wild animals such as red deer and rabbits (Moreno-García and Davis 2001; Davis 2006; Casal et al. 2009-2010, as cited in Valenzuela-Lamas et al. 2014). Indeed, Davis et al. (2008) note that, for Islam, the prohibition against pork consumption is less strictly applied to the wild boar, particularly in the Maghreb, where wild boar liver is consumed to gain the animal's strength (Simoons 1994; Moreno García 2004). Of course, the main point of difference between Christian populations and Jewish and Muslim groups is their consumption of pig (Valenzuela-Lamas et al. 2014).

Thus, it is possible that observant Jewish populations could be detected using faunal remains although zooarchaeological evidence for Jewish or, indeed, other religious practices is rare. The distribution (presence/absence) of kosher animals is the best way to identify a potential shift to a kosher diet and the appearance of the practice of Kashrut (Amar et al. 2009; Greenfield and Bouchnick 2011). Furthermore, the distribution of specific butchering patterns could be used to identify when the laws of shechita might have appeared in the archaeological record. At St Aldates, the remarkable feature of the faunal assemblage from structure 3.1 is that pig specimens are completely absent, while domestic fowl specimens (mainly goose) dominate, (astonishingly) being even more common than cattle bones. Fish bones from the feature, although limited, included herring, but no eel and only one fragment of marine shell. This animal bone assemblage (from phase 3) stands in sharp contrast to that of phase 2, in which pig bones were present in quantity and bird bones were barely seen, and, indeed, to the similar assemblage from the contemporaneous The Queen's College site. During the following phases at St Aldates, in the fourteenth and fifteenth centuries (phase 4), all properties represented at the site reverted to Christian ownership, indicated not least by the recovery of oyster shell, pig bones and eel bones from deposits associated with this phase (although these were not analysed). The pattern also contrasts with the assemblage recovered from phase 3 pits within area 1 at the site, again recorded, but not subject to detailed analysis. Notably, these features contained pig bones, marine shell and eel bones, and it is probable that the pits predate the latrine and relate to a period in the earlier part of the phase before the property was transferred to Jewish ownership.
As noted, one of the fundamental requirements of shechita, the traditional ritual slaughtering of animals, is the inspection of the carcass for any physiological abnormalities, where any injured or diseased animals are deemed non-kosher. This prohibition against consuming animals displaying signs of injury or disease suggests that there would be a very low incidence of pathologies in Jewish animal assemblages. However, as Valenzuela-Lamas et al. (2014) note, the inspection of carcasses is mainly fixed on the soft tissues. This suggests that skeletal pathologies would not necessarily be identified and that the lesions consistent with osteochondrosis on some of the St Aldates domestic cattle bones may not have been recognised.

The lipid residue results show that all vessels from phase 3 were solely used to process ruminant carcass products, in contrast to the Saxon assemblage (phases 1 and 2) and the contemporaneous medieval site at The Queen's College, where the majority of vessels appear to have been used to process mixtures of both ruminant and non-ruminant products. These data clearly suggest the avoidance of pig products during phase 3 and correlate well with the faunal data. It is also interesting that, despite the dominance of domestic fowl and goose in the phase 3 faunal assemblage, these do not seem to be processed in pots from the Jewish phase. Similarly to pigs, poultry are monogastric and omnivorous animals and, as such, would plot within the non-ruminant range (Colonese et al. 2017). This may suggest poultry were cooked by different means, possibly through roasting in ovens.

It could be argued that the Jewish inhabitants of the houses (or their forbears) may have absorbed influences from Norman foodways during their period of settlement in Northern France. Certainly, following the Conquest, zooarchaeological evidence suggests an increase in the consumption of both young pig and domestic fowl, this being most apparent in towns and at elite sites, such as castles, which is thought to reflect the influence of the Norman elite (Sykes 2007; Jervis et al. 2017). This trend was also observed among Oxford's Saxo-Norman population (Craig-Atkins et al. 2020). However, the complete absence of pig bones in phase 3 does not reflect this trend and the dominance of bird bones is far greater than that seen at other sites (Serjeantson 2006).

A further question raised by this study is the near absence of dairy products found in vessels from both sites and all phases $(n=3,5 \%)$, suggesting the vessels were not used to either heat milk or produce butter, cream or cheese from milk. This stands in contrast to a lipid residue study of late Saxon to early medieval pottery (AD 950 to 1450) from rural West Cotton, Northamptonshire (Dudd and Evershed 1998; Dunne et al. 2019), where dairy products were shown to play a significant part in the peasant diet (c. 25\%). However, West Cotton was an agricultural community, growing crops and managing cattle, sheep and pigs, and dairy products, sometimes referred to as 'white meats' of the poor, are thought to 
have been mainstays of the medieval peasant's diet (Woolgar 2016). The near absence of dairy lipids in the St Aldates vessels may be because dairy products were processed in different types of vessels (e.g. wooden bowls) or were perhaps not produced in individual households but rather purchased ready-made from sellers of butter and cheese. Certainly, milk is bulky to transport and would very quickly go off during summer months. It is interesting that milk is not mentioned in medieval City of London records as most other foods were (Hammond 1993). Converting milk to butter and cheese, in rural farming communities close to larger centres of population, offers better opportunities for preservation. The finished product could then easily be transported into towns and cities (Woolgar 2006) as demonstrated by the villeins from Pinhoe, Devon, who travelled 3 miles to bring cheese and butter to market in Exeter (Kowaleski 2003). It is known that butter and cheese were both heavily salted during the medieval period (presumably for preservation purposes), for example, in 1305, the Bishop of Winchester used $1 \mathrm{lb}$ of salt per $10 \mathrm{lb}$ of butter or cheese (Hammond 1993). Furthermore, producing cheese from milk could have been tied in with the medieval dairying season, allowing year-round consumption. At Cuxham, an Oxfordshire village, in 1351-1352, cheese was produced between the end of April and mid-August when most stock were lactating (Woolgar 2006). Interestingly, there was only one vessel (OXF029) in St Aldates phase 3 which was used to process dairy products. This vessel plots firmly within the dairy ellipse, suggesting it was used solely for dairy product processing, in accordance with the Jewish prohibition which requires the complete separation of meat and dairy products and associated equipment (Grivetti 1980; Regenstein et al. 2003).

The small fish assemblage from medieval contexts includes fish acquired from both coastal and freshwater fisheries. Much of the sea-fish, and probably also the salmon, is likely to have been preserved by pickling or salting, since transporting fresh fish to Oxford rapidly enough to avoid spoiling would have been expensive. Fish was, however, readily available, since their remains regularly feature in samples from the late Saxon period onwards in the city. In the early fourteenth century, fishmongers' stalls were located in Fish Street (now St Aldates), with permanent shops grouped in a side street known as Winchelsea Row, and by 1360 fishboards had been erected against properties near the town hall. In 1360, the fishmongers' stalls in St Aldates comprised 18 stalls for 'Winchelsea fish', and others for stockfish and herrings. To what extent the inhabitants of Jacob's Hall and surrounding properties enjoyed the fish is unclear, since the recovered assemblage is small for an urban site in the city, although this may simply be a reflection of the relatively small volume of sieved soil from rubbish deposits and cesspits. Likewise, the possibility of identifying a Jewish signature by the absence of eel is intriguing but would require a greater sample size and securely dated deposits to be conclusive.

To our knowledge, this is the first time that a Jewish dietary signature has been identified in British zooarchaeology, and just the third time in medieval Europe. An integrated study of faunal assemblages from two medieval sites (fourteenth century) in North-Eastern Spain (Catalonia), Tàrrega and Puigcerdà, yielded evidence of observant Jewish dietary practices. Both faunal assemblages came from special quarters the Jews were forced to live in, named 'call' in Catalan and 'judería' in Spanish (Bada 2009). Both assemblages were highly consistent, comprising solely kosher species, a predominance of forelimb bones and a scarcity of pelvic remains, together with regular butchery patterns. Faunal remains at both sites were dominated by sheep and goat, followed by birds at Tàrrega and cattle at Puigcerdà, most likely due to local ecological conditions. This study demonstrated the potential of zooarchaeology and taphonomy in detecting religious/cultural groups in the archaeological record and showed that both Jewish communities were clearly strictly observant of dietary laws (Valenzuela-Lamas et al. 2014).

A further example of a medieval Jewish Community, previously suggested by documentary and architectural evidence, was identified at the fourteenth-century settlement in the Buda Castle district, the Medieval royal capital of Hungary (Daróczi-Szabó 2004). Excavations of a 12-m-deep well within the former Teleki Palace yielded a fragment of a wooden plate decorated with a star of David and a glass fragment with Hebrew inscription. Deposits in this well were subdivided into an upper and lower section with the Jewish occupation being associated with the lower level. Comparison of the faunal assemblages from both layers revealed several notable differences. In the lower levels, only 3 pig bones $(0.2 \%)$ were found, in comparison to 97 (c. 4\%) in the upper, Christian occupation, level. Fish remains, although small in number, comprised scaled kosher fish, especially cyprinids and pike, in the lower level and scaleless non-kosher catfish in the upper levels. Also notable in the lower level was the small portion of hind leg elements, in comparison to the upper Christian level. This is likely to be related to the avoidance of meat from the hindquarters of domestic ruminants, related to the forbidden gid hanasheh or 'sinew of Jacob' (as discussed previously). The presence of a small number of hindleg bones might suggest that the joints were porged (deveined) although the number of cutmarks present in the sample was too small to test whether a higher ratio of cut marks occurs in the hind limb compared to those from the fore limb. Interestingly, Ijzereef (1989) also notes an absence of hind limb bones in food refuse from cess pits belonging to Sephardic households in seventeenth to eighteenth-century Amsterdam. Pig bones and eels were also absent but high quantities of chicken bones were found. Fish were present in lower abundances than nonJewish households. 


\section{Conclusion}

Here, the combination of organic residue analysis, site excavation and animal and fish bone evidence, confirmed that the inhabitants of two Jewish houses in eleventh- and twelfthcentury St Aldates, Oxford, practised keeping kosher, with its associated ritual food practices and taboos. This is the first identification of specific religious dietary practices using lipid residue analysis, verifying that, at least 800 years ago, medieval Jewish Oxford communities practised dietary laws known as Kashruth. This study demonstrates the future potential of a combined lipid analysis and archaeozoological approach to investigate religious dietary practices and, thus, cultural identities.

\section{Lipid residue analysis analytical methods}

Lipid analysis and interpretations were performed using established protocols described in detail in earlier publications (e.g. Dudd and Evershed 1998; Correa-Ascencio and Evershed 2014). All solvents used were of HPLC grade (Rathburn) and the reagents were of analytical grade (typically $>98 \%$ of purity). Briefly, $\sim 2 \mathrm{~g}$ of potsherd was sampled and surfaces cleaned with a modelling drill to remove exogenous lipids. The cleaned sherd powder was crushed in a solventwashed mortar and pestle and weighed into a furnaced culture tube (I). An internal standard was added $(40 \mu \mathrm{g} n$ tetratriacontane; Sigma-Aldrich Company Ltd) together with $5 \mathrm{~mL}$ of $\mathrm{H}_{2} \mathrm{SO}_{4} / \mathrm{MeOH} 2-4 \%\left(\delta^{13} \mathrm{C}\right.$ measured $)$ and the culture tubes were placed on a heating block for $1 \mathrm{~h}$ at $70^{\circ} \mathrm{C}$, mixing every $10 \mathrm{~min}$. Once cooled, the methanolic acid was transferred to test tubes and centrifuged at $2500 \mathrm{rpm}$ for $10 \mathrm{~min}$. The supernatant was then decanted into another furnaced culture tube (II) and $2 \mathrm{~mL}$ of DCM extracted double distilled water was added. In order to recover any lipids not fully solubilised by the methanol solution, $2 \times 3 \mathrm{~mL}$ of $n$-hexane was added to the extracted potsherds contained in the original culture tubes, mixed well and transferred to culture tube II. The extraction was transferred to a clean, furnaced $3.5 \mathrm{~mL}$ vial and blown down to dryness. Following this, $2 \times 2 \mathrm{~mL} n$-hexane was added directly to the $\mathrm{H}_{2} \mathrm{SO}_{4} / \mathrm{MeOH}$ solution in culture tube II and whirlimixed to extract the remaining residues, then transferred to the $3.5-\mathrm{mL}$ vials and blown down until a full vial of $n$-hexane remained. Aliquots of the TLE's were derivatised using $\mathrm{N}, \mathrm{O}$-bis(trimethylsilyl)trifluoroacetamide (BSTFA) containing 1\% trimethylchlorosilane (TMCS; Sigma-Aldrich Company Ltd.; $40 \mu \mathrm{L} ; 70{ }^{\circ} \mathrm{C}, 1 \mathrm{~h}$ ), excess BSTFA was removed under nitrogen and the derivatised TLE was dissolved in $n$-hexane prior to GC, GC-MS and GC-C-IRMS.

Firstly, the samples underwent gas chromatography using a gas chromatograph (GC) fitted with a high temperature nonpolar column (DB1-HT; 100\% dimethylpolysiloxane, $15 \mathrm{~m} \times$
$0.32 \mathrm{~mm}$ i.d., $0.1 \mu \mathrm{m}$ film thickness). The carrier gas was helium and the temperature programme comprised a $50{ }^{\circ} \mathrm{C}$ isothermal hold followed by an increase to $350^{\circ}$ at a rate of $10^{\circ} \mathrm{min}^{-1}$ followed by a 10-min isothermal hold. A procedural blank (no sample) was prepared and analysed alongside every batch of samples. Further compound identification was accomplished using gas chromatography-mass spectrometry (GC-MS). FAMEs were introduced by autosampler onto a GC-MS fitted with a non-polar column, $50 \mathrm{~m} \times 0.32 \mathrm{~mm}$ fused silica capillary column coated with an Rtx-1 stationary phase $(100 \%$ dimethylpolysiloxane, Restek, $0.17 \mu \mathrm{m})$. The instrument was a ThermoScientific Trace 1300 gas chromatograph coupled to an ISQ single quadrupole mass spectrometer. Samples were run in full scan mode $(\mathrm{m} / \mathrm{z}, 50-650)$ and the temperature programme comprised an isothermal hold at $50{ }^{\circ} \mathrm{C}$ for $1 \mathrm{~min}$, followed by a gradient increase to $300^{\circ} \mathrm{C}$ at $10{ }^{\circ} \mathrm{C} \mathrm{min}^{-1}$, followed by an isothermal hold at $300{ }^{\circ} \mathrm{C}$ $(15 \mathrm{~min})$. The MS was operated in electron ionisation (EI) mode operating at $70 \mathrm{eV}$. Data acquisition and processing were carried out using the HP Chemstation software (Rev. C.01.07 (27), Agilent Technologies) and Xcalibur software (version 3.0). Peaks were identified on the basis of their mass spectra and GC retention times, by comparison with the NIST mass spectral library (version 2.0).

Carbon isotope analyses by GC-C-IRMS were carried out using a GC Agilent Technologies 7890A coupled to an Isoprime 100 (EI, $70 \mathrm{eV}$, three Faraday cup collectors $\mathrm{m} / \mathrm{z}, 44,45$ and 46) via an IsoprimeGC5 combustion interface with a $\mathrm{CuO}$ and silver wool reactor maintained at $850{ }^{\circ} \mathrm{C}$. Instrument accuracy was determined using an external FAME standard mixture $\left(\mathrm{C}_{11}, \mathrm{C}_{13}, \mathrm{C}_{16}, \mathrm{C}_{21}\right.$ and $\mathrm{C}_{23}$ ) of known isotopic composition. Samples were run in duplicate and an average taken. The $\delta^{13} \mathrm{C}$ values are the ratios ${ }^{13} \mathrm{C} /{ }^{12} \mathrm{C}$ and expressed relative to the Vienna Pee Dee Belemnite, calibrated against a $\mathrm{CO}_{2}$ reference gas of known isotopic composition. Instrument error was $\pm 0.3 \%$. Data processing was carried out using Ion Vantage software (version 1.6.1.0, IsoPrime).

Supplementary Information The online version contains supplementary material available at https://doi.org/10.1007/s12520-021-01282-8.

Acknowledgements Any work involving medieval Oxford property records is indebted to H.E.Salter 1863-1951, who spent his life editing and diagramming Oxford property records from the 12th-16th centuries. The authors wish to thank NERC 771 (Reference: CC010) and NEIF (www. isotopesuk.org) for funding and maintenance of the instruments used for this work and Ian Bull and Alison Kuhl for technical help. The authors gratefully acknowledge Gilbert-Ash, with consultation by Orion Heritage, for commissioning the excavation and post-excavation projects on behalf of Reef Estates and the British Airways Pension Trust. The authors would like to thank Will Bedford of Orion Heritage and David Radford, Oxford City Council archaeologist, for their support throughout the archaeological programme. The fieldwork was 
managed by Carl Champness and directed on site by Vix Hughes and Ben Attfield. The post-excavation programme was managed by Edward Biddulph.

Author contributions JD and EB designed the project. JD, HW, TG, LGB, RN and PB carried out analysis. PM provided documents. JD wrote the paper with contributions from RPE, EB, LJEC, PM, LGB, RN, PB, $\mathrm{CC}, \mathrm{ST}, \mathrm{BJ}, \mathrm{ECA}, \mathrm{TH}$ and RM. All authors read and commented on the text.

Data availability All data are available in the paper.

\section{Compliance with ethical standards}

Conflict of interest The authors declare that there are no conflicts of interest.

Open Access This article is licensed under a Creative Commons Attribution 4.0 International License, which permits use, sharing, adaptation, distribution and reproduction in any medium or format, as long as you give appropriate credit to the original author(s) and the source, provide a link to the Creative Commons licence, and indicate if changes were made. The images or other third party material in this article are included in the article's Creative Commons licence, unless indicated otherwise in a credit line to the material. If material is not included in the article's Creative Commons licence and your intended use is not permitted by statutory regulation or exceeds the permitted use, you will need to obtain permission directly from the copyright holder. To view a copy of this licence, visit http://creativecommons.org/licenses/by/4.0/.

\section{References}

Albarella U (2006) Pig husbandry and pork consumption in medieval England. In: Woolgar CM, Serjeantson D, Oxford WT (eds) Food in medieval England: diet and nutrition. Oxford University Press, pp $72-87$

Alexander MM, Gerrard CM, Gutiérrez A, Millard AR (2015) Diet, society, and economy in late medieval Spain: stable isotope evidence from Muslims and Christians from Gandía, Valencia. Am J Phys Anthropol 156(2):263-273

Amar Z, Bouchnick R, Bar-Oz G (2009) The contribution of archaeozoology to the identification of the ritually clean ungulates mentioned in the Hebrew Bible. J Hebrew Scriptures 10:2-24

Bada JL (2009) L'Expulsió dels jueus, 1492. Butlletí de la Societat Catalana d'Estudis Històrics:51-68

Baker P and Worley FL (2014) Animal bones and archaeology: guidelines for best practice

Berstan R, Stott AW, Minnitt S, Ramsey CB, Hedges REM, Evershed RP (2008) Direct dating of pottery from its organic residues: new precision using compound-specific carbon isotopes. Antiquity 82(317): 702-713

Brettell RC, Stern B, Reifarth N, Heron C (2014) The 'semblance of immortality'? Resinous materials and mortuary rites in Roman Britain. Archaeometry 56(3):444-459

Brettell RC, Schotsmans EMJ, Walton Rogers P, Reifarth N, Redfern RC, Stern B et al (2015a) 'Choicest unguents': molecular evidence for the use of resinous plant exudates in late Roman mortuary rites in Britain. J Archaeol Sci 53:639-648
Brettell RC, Stern B and Heron C (2015b) Mersea Island Barrow: molecular evidence for frankincense. The Essex Society for Archaeology and History 4

Caplan P (1997) Approaches to the study of food, health and identity. In: Caplan P (ed) Food, health and identity. Routledge, London, pp 131

Casal MT, Martínez RM, Araque MM (2009-2010) Estudio de los vertederos domésticos del arrabal de Saqunda: ganadería, alimentación y usos derivados (750-818 dC)(Córdoba). Anejos de anales de arqueología cordobesa 2:143-182

Cesaro MC (2000) Consuming identities: food and resistance among the Uyghur in contemporary Xinjiang. Inner Asia 2(2):225-238

Charters S, Evershed RP, Goad LJ, Heron C, Blinkhorn P (1993) Identification of an adhesive used to repair a Roman jar. Archaeometry 35:91-101

Cohen A, Serjeantson D (1996) A manual for the identification of bird bones from archaeological sites. Archetype Publications

Colonese AC, Lucquin A, Guedes EP, Thomas R, Best J, Fothergill BT, Sykes N, Foster A, Miller H, Poole K, Maltby M, von Tersch M, Craig OE (2017) The identification of poultry processing in archaeological ceramic vessels using in-situ isotope references for organic residue analysis. J Archaeol Sci 78:179-192

Copley MS, Berstan R, Dudd SN, Docherty G, Mukherjee AJ, Straker V, Payne S, Evershed RP (2003) Direct chemical evidence for widespread dairying in Prehistoric Britain. Proc Natl Acad Sci U S A 100(4):1524-1529

Copley MS, Hansel FA, Sadr K, Evershed RP (2004a) Organic residue evidence for the processing of marine animal products in pottery vessels from the pre-colonial archaeological site of Kasteelberg D east, South Africa. S Afr J Sci 100(5-6):279-283

Copley MS, Jim S, Jones V, Rose P, Clapham A, Edwards DN, Horton M, Rowley-Conwy P, Evershed RP (2004b) Short- and long-term foraging and foddering strategies of domesticated animals from Qasr Ibrim, Egypt. J Archaeol Sci 31(9):1273-1286

Copley MS, Berstan R, Dudd SN, Straker V, Payne S, Evershed RP (2005a) Dairying in antiquity. I. Evidence from absorbed lipid residues dating to the British Iron Age. J Archaeol Sci 32(4):485-503

Copley MS, Berstan R, Mukherjee AJ, Dudd SN, Straker V, Payne S et al (2005b) Dairying in antiquity. III. Evidence from absorbed lipid residues dating to the British Neolithic. J Archaeol Sci 32(4):523546

Copley MS, Berstan R, Straker V, Payne S, Evershed RP (2005c) Dairying in antiquity. II. Evidence from absorbed lipid residues dating to the British Bronze Age. J Archaeol Sci 32(4):505-521

Correa-Ascencio M, Evershed RP (2014) High throughput screening of organic residues in archaeological potsherds using direct acidified methanol extraction. Anal Methods 6(5):1330-1340

Craig OE, Chapman J, Figler A, Patay P, Taylor G, Collins MJ (2003) Milk jugs' and other myths of the Copper Age of Central Europe. Eur J Archaeol 6(3):251-265

Craig OE, Forster M, Andersen SH, Koch E, Crombe P, Milner NJ et al (2007) Molecular and isotopic demonstration of the processing of aquatic products in northern European prehistoric pottery. Archaeometry 49:135-152

Craig-Atkins E, Jervis B, Cramp L, Hammann S, Nederbragt AJ, Nicholson E et al (2020) The dietary impact of the Norman Conquest: a multiproxy archaeological investigation of Oxford, UK. PLoS One 15(7)

Cramp L, Evershed RP (2014) Reconstructing aquatic resource exploitation in Human Prehistory using lipid biomarkers and stable isotopes. In: Holland HD, Turekian KK (eds) Treatise on Geochemistry, 2nd edn. Elsevier, Oxford, pp 319-339

Cramp LJE, Evershed RP, Lavento M, Halinen P, Mannermaa K, Oinonen $\mathrm{M}$ et al (2014a) Neolithic dairy farming at the extreme of agriculture in northern Europe. Proc R Soc B Biol Sci 281(1791) 
Cramp LJE, Jones J, Sheridan A, Smyth J, Whelton H, Mulville J et al (2014b) Immediate replacement of fishing with dairying by the earliest farmers of the northeast Atlantic archipelagos. Proc R Soc B Biol Sci 281(1780)

Daróczi-Szabó L (2004) Animal bones as indicators of kosher food refuse from 14th century AD Buda, Hungary. In: O'Day SJ, van Neer W, Ervynck A (eds) Behaviour behind bones: the zooarchaeology of ritual, religion, status and identity. Oxbow Books, Oxford, pp 252261

Davis SJ (2006) Faunal remains from Alcáçova de Santarém, Portugal, Instituto português de arqueologia

Davis SJM, Gonçalves MJ, Gabriel S (2008) Animal remains from a Moslem period (12th/13th century AD) lixeira (garbage dump) in Silves, Algarve, Portugal. Rev Port Arqueol 11(1):183-258

Debono Spiteri C, Gillis RE, Roffet-Salque M, Castells Navarro L, Guilaine J, Manen C, Muntoni IM, Saña Segui M, Urem-Kotsou D, Whelton HL, Craig OE, Vigne JD, Evershed RP (2016) Regional asynchronicity in dairy production and processing in early farming communities of the northern Mediterranean. Proc Natl Acad Sci 113(48):13594-13599

Dudd SN, Evershed RP (1998) Direct demonstration of milk as an element of archaeological economies. Science 282(5393):1478-1481

Dunne J, Evershed RP, Salque M, Cramp L, Bruni S, Ryan K, Biagetti S, di Lernia $S$ (2012) First dairying in green Saharan Africa in the fifth millennium BC. Nature 486(7403):390-394

Dunne J, Mercuri AM, Evershed RP, Bruni S, di Lernia S (2016) Earliest direct evidence of plant processing in prehistoric Saharan pottery. Nat Plants 3:1-6

Dunne J, di Lernia S, Chłodnicki M, Kherbouche F, Evershed RP (2017) Timing and pace of dairying inception and animal husbandry practices across Holocene North Africa. Quat Int 471:147-159

Dunne J, Chapman A, Blinkhorn P, Evershed RP (2019) Reconciling organic residue analysis, faunal, archaeobotanical and historical records: diet and the medieval peasant at West Cotton, Raunds, Northamptonshire. J Archaeol Sci 107:58-70

Durham B (1977) Archaeological investigations in St Aldates, Oxford. Oxoniensia 42:83-203

Dyer C (1998) Standards of living in the later middle ages. Social change in England c1200-1520. Cambridge University Press, Cambridge

Ethier J, Bánffy E, Vuković J, Leshtakov K, Bacvarov K, Roffet-Salque M, Evershed RP, Ivanova M (2017) Earliest expansion of animal husbandry beyond the Mediterranean zone in the sixth millennium BC. Sci Rep 7(1):7146

Evershed RP (2008) Experimental approaches to the interpretation of absorbed organic residues in archaeological ceramics. World Archaeol 40(1):26-47

Evershed RP, Heron C, Goad LJ (1991) Epicuticular wax components preserved in potsherds as chemical indicators of leafy vegetables in ancient diets. Antiquity 65(248):540-544

Evershed RP, Stott AW, Raven A, Dudd SN, Charters S, Leyden A (1995) Formation of long-chain ketones in ancient pottery vessels by pyrolysis of acyl lipids. Tetrahedron Lett 36(48):8875-8878

Evershed RP, Mottram HR, Dudd SN, Charters S, Stott AW, Lawrence GJ, Gibson AM, Conner A, Blinkhorn PW, Reeves V (1997a) New criteria for the identification of animal fats preserved in archaeological pottery. Naturwissenschaften 84(9):402-406

Evershed RP, Vaughan SJ, Dudd SN, Soles JS (1997b) Fuel for thought? Beeswax in lamps and conical cups from late Minoan Crete. Antiquity 71(274):979-985

Evershed RP, Dudd SN, Copley MS, Berstan R, Stott AW, Mottram H, Buckley SA, Crossman Z (2002) Chemistry of archaeological animal fats. Acc Chem Res 35(8):660-668

Evershed RP, Payne S, Sherratt AG, Copley MS, Coolidge J, UremKotsu D, Kotsakis K, Özdoğan M, Özdoğan AE, Nieuwenhuyse O, Akkermans PMMG, Bailey D, Andeescu RR, Campbell S, Farid S, Hodder I, Yalman N, Özbașaran M, Bıçakcı E, Garfinkel
Y, Levy T, Burton MM (2008) Earliest date for milk use in the Near East and southeastern Europe linked to cattle herding. Nature 455(7212):528-531

Freedman SE (1970) The book of Kashruth. Freedman, New York

Goody J (1982) Cooking, cuisine and class: a study in comparative sociology. Cambridge University Press, Cambridge

Grau-Sologestoa I (2017) Socio-economic status and religious identity in medieval Iberia: the zooarchaeological evidence. Environ Archaeol 22(2):189-199

Greenfield H, Bouchnick R (2011) Kashrut and Shechita: the relationship between dietary practices and ritual slaughtering of animals on Jewish identity. Identity Crisis: Archaeological Perspectives on Social Identity:106-120

Greenspoon L, Simkins JR, Shapiro G (2005) Food and Judaism. Creighton University Press, Omaha

Gregg MW, Banning EB, Gibbs K, Slater GF (2009) Subsistence practices and pottery use in Neolithic Jordan: molecular and isotopic evidence. J Archaeol Sci 36(4):937-946

Grivetti LE (1980) Dietary separation of meat and milk a culturalgeogmaphical inquiry. Ecol Food Nutr 9(4):203-217

Grunfeld DI (1972) The Jewish Dietary Laws. The Soncino Press, New York

Hamilakis Y (2000) The anthropology of food and drink consumption and Aegean archaeology. Palaeodiet in the Aegean 55:63

Hammond P (1993) Food and feast in medieval England. Sutton Publishing Ltd, Stroud

Hansel FA, Evershed RP (2009) Formation of dihydroxy acids from Zmonounsaturated alkenoic acids and their use as biomarkers for the processing of marine commodities in archaeological pottery vessels. Tetrahedron Lett 50(40):5562-5564

Hansel FA, Copley MS, Madureira LAS, Evershed RP (2004) Thermally produced [omega]-(o-alkylphenyl)alkanoic acids provide evidence for the processing of marine products in archaeological pottery vessels. Tetrahedron Lett 45(14):2999-3002

Heron C, Craig OE, Luquin A, Steele VJ, Thompson A, Piličiauskas G (2015) Cooking fish and drinking milk? Patterns in pottery use in the southeastern Baltic, 3300-2400 Cal BC. J Archaeol Sci 63:33-43

Hinton DA (2003) Medieval Anglo-Jewry: the archaeological evidence. In: Skinner P (ed) Jews in Medieval Britain: historical, literary and archaeological perspectives. Boydell Press, Woodbridge, Suffolk, pp 97-111

Ijzereef FG (1989) Social differentiation from animal bone studies. In: Serjeantson D, Waldron T (eds) Diet and craft in towns: the evidence of animal remains from the Roman to the post-medieval periods. Oxford, British Archaeological Reports British Series, vol 199, pp 41-53

Jervis B, Whelan F, Livarda A (2017) Cuisine and conquest: interdisciplinary perspectives on food, continuity and change in 11th-century England and beyond. In: Hadley DM, Dyer C (eds) The archaeology of the eleventh century: continuities and transformations. Routledge, London, pp 244-262

Kowaleski M (2003) Local markets and regional trade in medieval Exeter. Cambridge University Press

Kraemer D (2005) Separating the dishes: the history of a Jewish eating practice. In: Greenspoon LJ, Simkins RA, Shapiro G (eds) Food and Judaism. Creighton University Press, Omaha, pp 235-256

Kraut AM (1979) Ethnic foodways: the significance of food in the designation of cultural boundaries between immigrant groups in the US, 1840-1921. J Am Cult 2(3):409-420

Manix P (2004) Oxford: mapping the medieval Jewry. The Jews of Europe in the Middle Ages (Tenth to Fifteenth Centuries): Proceedings of the International Symposium Held at Speyer, 2025 October 2002, Brepols Publishers

Mellor M (1994) Oxford pottery: a synthesis of Middle and Late Saxon, Medieval and Early Post-Medieval Pottery in the Oxford Region. Oxoniensia 59:17-217 
Mileto S, Kaiser E, Rassamakin Y, Evershed RP (2017) New insights into the subsistence economy of the Eneolithic Dereivka culture of the Ukrainian North-Pontic region through lipid residues analysis of pottery vessels. J Archaeol Sci Rep 13:67-74

Mintz SW, Du Bois CM (2002) The anthropology of food and eating. Annu Rev Anthropol 31(1):99-119

Moreno García M (2004) Manejo y aprovechamiento de las cabañas ganaderas en las comunidades rifeñas marroquíes

Moreno-García M and Davis S (2001) Estudio de las asociaciones faunísticas recuperadas en Alcácer do Sal, Convento de São Francisco, Santarém y Sé de Lisboa. Garb, Sítios Islâmicos do Sul de Portugal: 231-255

Mottram HR, Dudd SN, Lawrence GJ, Stott AW, Evershed RP (1999) New chromatographic, mass spectrometric and stable isotope approaches to the classification of degraded animal fats preserved in archaeological pottery. J Chromatogr A 833(2):209-221

Outram AK, Stear NA, Bendrey R, Olsen S, Kasparov A, Zaibert V, Thorpe N, Evershed RP (2009) The earliest horse harnessing and milking. Science 323(5919):1332-1335

Raven AM, van Bergen PF, Stott AW, Dudd SN, Evershed RP (1997) Formation of long-chain ketones in archaeological pottery vessels by pyrolysis of acyl lipids. J Anal Appl Pyrolysis 40-41(0):267-285

Regenstein JM and Regenstein CE (1979) An introduction to the kosher dietary laws for food scientists and food processors. Food Technology (USA)

Regenstein JM, Regenstein CE (1988) The kosher dietary laws and their implementation in the food-industry. Food Technol 42(6):86

Regenstein JM, Regenstein CE (1991) Current issues in kosher foods. Trends Food Sci Technol 2:50-54

Regenstein JM, Chaudry MM, Regenstein CE (2003) The Kosher and Halal Food Laws. Compr Rev Food Sci Food Saf 2(3):111-127

Roffet-Salque M, Regert M, Evershed RP, Outram AK, Cramp LJE, Decavallas O, Dunne J, Gerbault P, Mileto S, Mirabaud S, Pääkkönen M, Smyth J, Šoberl L, Whelton HL, Alday-Ruiz A, Asplund H, Bartkowiak M, Bayer-Niemeier E, Belhouchet L, Bernardini F, Budja M, Cooney G, Cubas M, Danaher EM, Diniz M, Domboróczki L, Fabbri C, González-Urquijo JE, Guilaine J, Hachi S, Hartwell BN, Hofmann D, Hohle I, Ibáñez JJ, Karul N, Kherbouche F, Kiely J, Kotsakis K, Lueth F, Mallory JP, Manen C, Marciniak A, Maurice-Chabard B, Mc Gonigle MA, Mulazzani S, Özdoğan M, Perić OS, Perić SR, Petrasch J, Pétrequin AM, Pétrequin P, Poensgen U, Joshua Pollard C, Poplin F, Radi G, Stadler P, Stäuble H, Tasić N, Urem-Kotsou D, Vuković JB, Walsh F, Whittle A, Wolfram S, Zapata-Peña L, Zoughlami J (2015) Widespread exploitation of the honeybee by early Neolithic fermers. Nature 527(7577):226-230

Roffet-Salque M, Dunne J, Altoft DT, Casanova E, Cramp LJE, Smyth J, Whelton HL, Evershed RP (2017) From the inside out: upscaling organic residue analyses of archaeological ceramics. J Archaeol Sci Rep 16:627-640

Rosenblum JD (2010) Food and identity in Early Rabbinic Judaism. Cambridge University Press, Cambridge

Serjeantson D (1996) Animal bone. In: Needham S, Spence T (eds) Refuse and disposal at Area 16 East, Runnymede, Runnymede Bridge Research Excavations, Volume 2. London, British Museum Press, pp 194-223

Serjeantson D (2006) Birds: food and a mark of status. In: Woolgar CM, Serjeantson D, Waldron T (eds) Food in Medieval England. Oxford University Press, Oxford, pp 131-147
Sewell L (2010) Osteochondrosis in sheep and cattle: differential diagnosis and estimating prevalence. Unpublished MSc in Zooarchaeology, University of York

Simoons FJ (1994) Eat not this flesh: food avoidances from prehistory to the present, University of Wisconsin Press

Smyth JR, Evershed RP (2015) Milking the megafauna: using organic residue analysis to understand early farming practice. Environ Archaeol 21(3):214-229

Spangenberg JE, Jacomet S, Schibler J (2006) Chemical analyses of organic residues in archaeological pottery from Arbon Bleiche 3, Switzerland - evidence for dairying in the late Neolithic. J Archaeol Sci 33(1):1-13

Stacey RJ, Dunne J, Brunning S, Devièse T, McIntyre L, Mortimer R et al (2020) Birch bark tar in early Medieval England - continuity of tradition or technological revival? J Archaeol Sci Rep 29:102118

Stone DJ (2006) The consumption and supply of birds in Late Medieval England. In: Woolgar CM, Serjeantson D, Waldron T (eds) Food in Medieval England. Oxford University Press, Oxford, pp 148-161

Sykes NJ (2007) The Norman conquest: a zooarchaeological perspective. BAR International Series 1656. Oxford: Archaeopress

Teague S and Brown R (2020) Anglo-Saxon to post-Medieval occupation at the Provost's Garden, The Queen's College'. In: A. Dodd, S. Mileson and L. Webley (Eds.). The archaeology of Oxford in the twenty-first century. Investigations in the City by Oxford archaeology, 2006-16. Woodbridge: Boydell and Brewer: 139-200

Teague S, Biddulph E and Champness C (2020) Anglo-Saxon to postmedieval occupation and evidence for the Medieval Jewry at Nos. 114-19 St Aldate's and Nos. 4-5 Queen Street'. In: A. Dodd, S. Mileson and L. Webley (Eds.) The archaeology of Oxford in the twenty-first century. investigations in the City by Oxford archaeology, 2006-16. Woodbridge: Boydell and Brewer: 73-126

Toso A, Gaspar S, Banha da Silva R, Garcia SJ, Alexander M (2019) High status diet and health in Medieval Lisbon: a combined isotopic and osteological analysis of the Islamic population from São Jorge Castle, Portugal. Archaeol Anthropol Sci 11(8):3699-3716

Tuchman G, Levine HG (1993) New York Jews and Chinese food: the social construction of an ethnic pattern. J Contemp Ethnogr 22(3): 382-407

Twiss K (2012) The archaeology of food and social diversity. J Archaeol Res 20(4):357-395

Urem-Kotsou D, Stern B, Heron C, Kotsakis K (2002) Birch-bark tar at Neolithic Makriyalos, Greece. Antiquity 76(294):962-967

Valenzuela-Lamas S, Valenzuela-Suau L, Saula O, Colet A, Mercadal O, Subiranas C, Nadal J (2014) Shechita and kashrut: identifying Jewish populations through zooarchaeology and taphonomy. Two examples from Medieval Catalonia (North-Eastern Spain). Quat Int 330:109-117

Whelton HL, Roffet-Salque M, Kotsakis K, Urem-Kotsou D, Evershed RP (2018) Strong bias towards carcass product processing at Neolithic settlements in northern Greece revealed through absorbed lipid residues of archaeological pottery. Quat Int 496:127-139

Woolgar CM (2006) Meat and dairy products in Late Medieval England. In: Woolgar CM, Serjeantson D, Waldron T (eds) Food in Medieval England: diet and nutrition. Oxford University Press, Oxford, pp $88-101$

Woolgar CM (2016) The culture of food in England, 1200-1500. Yale University Press

Publisher's note Springer Nature remains neutral with regard to jurisdictional claims in published maps and institutional affiliations. 